\title{
Bartosz ŚWIATŁOWSKI
}

b.swiatlowski@gmail.com

\section{PROMETEJSKA RACJA STANU}

\section{ŹRÓDŁA I DZIEJE RUCHU PROMETEJSKIEGO W II RZECZPOSPOLITEJ}

ABSTRACT The Promethean reason of the state. The history of the Promethean movement in the Second Polish Republic

Prometheism, which started to develop in 1921, after the Polish-Bolshevik Peace of Riga, was both an ideological and political project. The idea of liberating nations oppressed by the Soviet Union was accompanied by publishing activities, institutional and community network. The article presents the genesis of Prometheism, its geopolitical and historical sources, political provenance of its main activists, evolution of the movement in the 1930 s and the institutional dimension of Polish Prometheists. The paper also discusses the most important views of the creators of the movement, including thoughts on Russian imperialism, solidarity with enslaved nations and the united fight for "our freedom and yours", originating both in the sense of mission and the analysis of the Republic of Poland's reason of state. The author focuses on two important elements of the movement - the realism of the political concept and the Promethean elite's political thought about the state, the nation and the geopolitics of Eastern Europe.

KEYWORDS prometheism, geopolitics, Europe, communism, sovereignty

\section{WSTĘP}

Ruch prometejski rozwijany od narodzin II Rzeczpospolitej, a ściślej od 1921 r., a więc od podpisania polsko-sowieckiego traktatu ryskiego ${ }^{1}$, był przedsięwzięciem zarówno

Traktat pokoju między Polska a Rosją i Ukraina, podpisany w Rydze dnia 18 marca 1921 r., Dz. U. 1921, nr 49, poz. 300 . 
z dziedziny myśli politycznej, jak i bieżącej polityki. Idei wyzwolenia narodów spod wpływu Rosyjskiej Federacyjnej Socjalistycznej Republiki Radzieckiej (RFSRR) towarzyszyła realistyczna, wywiadowcza oraz wydawnicza praca codzienna, wokół której budowano siatkę instytucjonalno-środowiskową.

Niniejszy artykuł przedstawia początki historii ruchu prometejskiego, jego źródła geopolityczne i historyczne, proweniencję polityczną głównych działaczy, ewolucję ruchu w latach 30 . XX w. oraz instytucjonalny wymiar działalności polskich prometeistów. Przedstawione w nim zostały najistotniejsze poglądy twórców prometeizmu na zagadnienia rosyjskiego imperializmu, solidarności z „narodami zniewolonymi” i wypływającej zarówno z poczucia misji, jak i z analizy racji stanu Rzeczpospolitej wspólnej walki „za wolność naszą i waszą”. Autor skupił się na dwóch ważnych komponentach ruchu prometejskiego - realizmie koncepcji politycznej oraz sposobie politycznego myślenia elity prometejskiej o własnym państwie, narodzie, a także o geopolityce Europy Środkowo-Wschodniej. Temat ten wymaga więc analizy dwojakiego rodzaju. Z jednej strony należy przedstawić dorobek prometeizmu w stosunkach międzynarodowych, dyplomacji, pracy badawczej oraz działalności instytucji naukowych i wydawniczych. $Z$ drugiej - konieczne jest przedstawienie prometeizmu jako istotnej części polskiej myśli politycznej.

W trzech pierwszych częściach przedstawiono główne racje ideowe i geopolityczne koncepcji prometejskiej. Opisane zostały także dwie inne ważne kwestie - sposób postrzegania politycznej roli II Rzeczpospolitej w regionie Europy Środkowo-Wschodniej oraz ocena istoty rosyjskiego imperializmu zagrażającego państwom powstałym po 1918 r. Ta część artykułu stanowi szkic filozofii politycznej prometeizmu, wpisującej się w bogatą tradycję wolnościowej polskiej myśli politycznej. Prometeizm jawi się jako próba eksportu wolności do innych państw i narodów, dokonująca się nie tylko w związku z aktualnym poczuciem ucisku, ale i szerszym, niejako ponadczasowym, uznawaniem wolności za wartość kluczową dla przetrwania wspólnoty politycznej. Obok tego rodzaju metapolitycznych źródeł artykuł prezentuje również zaplecze naukowo-badawcze i instytucjonalne ruchu oraz zmiany w myśleniu jego twórców na przestrzeni lat 30. XX w.

Mit o Prometeuszu, greckim tytanie, to opowieść o postaci poświęcającej się dla dobra ludzkości w imię uniwersalnej wartości, jaką jest wolnośćc ${ }^{2}$ Polityka zagraniczna, do której odnosił się prometeizm w II RP, to zaś najczęściej domena realpolitik, niekiedy zbieżnych, ale częściej sprzecznych interesów poszczególnych państw, wymagająca raczej zdolności kalkulacji i syntetycznej analizy aniżeli wzniosłych idei. Jak jednak pokazuje historia ruchu prometejskiego, łączenie tych dwóch pozornie osobnych światów wcale nie musi być skazane na porażkę. Co więcej, doświadczenie prometeizmu pozwala dostrzec realistyczne sposoby zaprzęgania idei do konkretnych i wymiernych treści codziennych zmagań politycznych. Za najkrótszą definicję prometeizmu można uznać słowa Józefa Piłsudskiego z 1904 r.: rozbicie państwa rosyjskiego na gtówne części sktadowe i usamowolnienie przemoca wcielonych w sktad Imperium

W. Kopaliński, Stownik mitów i tradycji kultury, Warszawa 1985, s. 932. 
krajów ${ }^{3}$. Już w tych wczesnych słowach przyszłego Naczelnika Państwa i zwolennika ruchu prometejskiego widać dwa fundamentalne założenia koncepcji: wspieranie niepodległościowych aspiracji narodów zniewolonych przez carskie, a później sowieckie imperium oraz, ipso facto, dążenie do jego dezintegracji. Autorem samego pojęcia prometeizmu, jako pewnego programu działania państwa polskiego i jego głównych organów, z Wydziałem Wschodnim Ministerstwa Spraw Zagranicznych oraz Oddziałem II Sztabu Generalnego (od 1928 r. Sztabu Głównego) Wojska Polskiego (wywiad) na czele, miał być płk Tadeusz Schaetzel, oficer, a następnie pracownik wspomnianego urzędu ${ }^{4}$. Prometeizm, choć nie stał się nigdy oficjalną doktryną polityki zagranicznej II RP $\mathrm{P}^{5}$, był ważnym instrumentem realizacji polskich interesów, w szczególności na odcinku wschodnim.

Już na wstępie warto wspomnieć, że tworzenie prometeizmu wynikało z co najmniej trzech istotnych przesłanek: a) braku szans na realizację federacyjnej koncepcji marszałka Piłsudskiego, b) procesów narodowo-wyzwoleńczych w latach 1917-1920, czyli wybijania się na niepodległość Finlandii, państw bałtyckich, wschodnich sąsiadów Polski i państw kaukaskich, c) swego rodzaju prometeizm à rebours, który stosowała po przegranej wojnie polsko-bolszewickiej Rosja sowiecka ${ }^{6}$. Ta ostatnia okoliczność, będąca przejawem głębszej i dużo starszej strategii imperialnego podboju, skłoniła Włodzimierza Bączkowskiego, jednego z czołowych publicystów prometejskich, do następującej definicji akcji prometejskiej: Prometeizm, tączący w sobie treść wielkiej idei wolności ludów podbitych przez Rosję z technika politycznego rozktadu Rosji, to oręż, który jest jedyna wtaściwa odpowiedziq na metody i taktykę rosyjsko-sowiecka ${ }^{7}$.

\section{INSPIRACJE, ŹRÓDŁA, ZASIĘG PROMETEIZMU}

Odrodzenie państwa polskiego po 123 latach $^{8}$ było konsekwencją wielu czynników, zwłaszcza wielkiego konfliktu zbrojnego mocarstw. Okoliczność upadku imperiów Austro-Węgier, Niemiec, a przede wszystkim Rosji sprawiła, że powstał szereg nowych

\footnotetext{
P. Libera, Polski prometeizm, jak ewoluowat i jak z nim walczono?, „Pressje” 2010, nr 22-23, s. 89.

4 M. Kornat, Ruch prometejski - ważne doświadczenie polityki zagranicznej II Rzeczypospolitej, „Nowa Europa Wschodnia" 2008, nr 2, s. 77.

5 Tenże, Idea prometejska a polska polityka zagraniczna (1921-1939/1940), [w:] Ruch prometejski i walka o przebudowę Europy Wschodniej (1918-1940). Studia i szkice, red. tenże, Warszawa 2012, s. 35-90.

6 Szerzej na ten temat zob. J. J. Bruski, Między prometeizmem a Realpolitik. II Rzeczpospolita wobec Ukrainy sowieckiej 1921-1926, Kraków 2010, s. 217-307, Studia z Historii XX Wieku, t. 10.

7 W. Bączkowski, Uwagi o istocie sity rosyjskiej, [w:] tenże, O wschodnich problemach Polski. Wybór pism, wybór i wstęp J. Kloczkowski, P. Kowal, Kraków 2000, s. 134, Biblioteka Myśli Politycznej, 32.

8 123-letni okres dzielący trzeci rozbiór Polski od odzyskania niepodległości w 1918 r. był również czasem istnienia takich form państwowych, jak Księstwo Warszawskie czy Królestwo Polskie. Jednak nie zmienia to faktu, że Rzeczpospolita pozostawała przedmiotem gry wielkich imperiów, a nie samodzielnym podmiotem.
} 
państw, powołanych przez narody dotąd w większym lub mniejszym stopniu uciskane przez silniejsze organizmy państwowe. Na przebieg powojennych granic wpływ miały państwa zachodnie z Francją i Wielką Brytanią na czele?. Okoliczności geopolityczne wskazywały, że ów porządek nosi znamiona chwiejnej i kruchej konstrukcji, zależnej od państw zwycięskich, narażonej na konflikty graniczne i narodowościowe, a także zagrożonej przez niemiecką kontestację powojennego ładu i bolszewizm. Szczególnie ów ostatni czynnik, wraz z nakładającym się nań zagadnieniem dążenia do narodowej niezawisłości Litwy, Ukrainy i Białorusi, sprawiał, że kwestia wschodniej granicy Rzeczpospolitej nabierała kluczowego znaczenia.

Na tak zarysowaną problematyczną sytuację Polski Piłsudski ${ }^{10}$ chciał odpowiedzieć w interesujący sposób. Koncepcja federalizmu przewidywała oderwanie od Rosji zagarniętych ziem I Rzeczpospolitej ${ }^{11}$ i ścisłą federację z historycznym fundamentem państwa wielonarodowego - Litwą ${ }^{12}$. Plan swego rodzaju „wschodniego mocarstwa” byłby jednak niekompletny bez udziału Ukrainy i Białorusi ${ }^{13}$. Litwa miała być gwarantem

9 System sojuszy między państwami europejskimi zaczął się kształtować jeszcze pod koniec XIX w. Umowa Niemiec z Austro-Węgrami z 1879 r. oraz późniejsze porozumienie z Włochami doprowadziły do powstania trójprzymierza. W przeciwnym obozie znalazły się Francja i Rosja (w wyniku porozumienia z 1892 r.) oraz Wielka Brytania złączona „serdecznym porozumieniem” (fr. enente cordiale) z Francją i późniejszym sojuszem z Rosją. Tuż przed wojną i w jej trakcie do mocarstw europejskich przyłączały się inne państwa. W skład trójprzymierza weszły Turcja i Bułgaria, natomiast ententę zasiliły przede wszystkim Stany Zjednoczone, ale również zmieniające w trakcie wojny sojuszników Włochy. Siły polityczne i wojskowe Rzeczpospolitej działały i walczyły po obu stronach, zgodnie z własnymi wizjami odzyskania niepodległości. Rosja w wyniku rewolucji bolszewickiej 1917 r. zrezygnowała z uczestnictwa w entencie.

10 W tamtym czasie, tj. w latach 1918-1922, Józef Piłsudski sprawował funkcję Naczelnika Państwa, co oznaczało najwyższą władzę cywilną, wykonawczą i wojskową. Wola i wizja Piłsudskiego mogły być wcielane w życie, gdyż miał on formalnoprawną swobodę kształtowania organów państwa (z Radą Ministrów na czele) gwarantowaną przez zatwierdzenie Sejmu Ustawodawczego z 20 II 1919 r. i (ograniczającą kompetencje Naczelnika) Małą Konstytucją z 1919 r.

11 Na tzw. ziemie zabrane na Kresach wschodnich składały się tereny anektowane przez Rosję w wyniku pierwszego rozbioru (Inflanty Polskie, województwa witebskie, mścisławskie, północna część połockiego oraz południowo-wschodnie tereny mińskiego), drugiego rozbioru (woj. kijowskie, bracławskie, wschodnie części wołyńskiego i brzeskiego, resztki mińskiego oraz część wileńskiego), wreszcie trzeciego rozbioru (pozostałe ziemie na wschód od Bugu, niezajęte jeszcze ziemie Wielkiego Księstwa Litewskiego oraz obwód białostocki). Łączna powierzchnia tego terytorium to 462 tys. km², zamieszkiwanych na początku XX w. przez około 25-26 mln ludzi, w tym około 5-6 mln Polaków.

12 A. Nowak, Historie politycznych tradycji. Pitsudski, Putin i inni, Kraków 2007, s. 186-187, Arkana Historii.

13 Po rewolucji październikowej w Rosji część Ukrainy proklamowała autonomię, a z czasem niepodległość jako Ukraińska Republika Ludowa (URL), upatrująca gwaranta niezawisłości w Niemcach. Powstała równieżZachodnioukraińska Republika Ludowa (ZURL) składająca się z polityków z Galicji Wschodniej, Bukowiny i Rusi Zakarpackiej, reprezentujących opcję proaustriacką. Posunięcia te oznaczały konflikty z Rosją oraz Polską. Na początku 1919 r. nastąpiło zjednoczenie URL i ZURL, prowadzące do wojny z Polską. Nieprzejednanego stanowiska polityków ZURL wobec granicy z Polską nie podzielał Symon Petlura, który w tym czasie objął przewodnictwo w tzw. Dyrektoriacie powstałym po wycofaniu się Niemiec i dotychczasowego przywódcy URL Pawła Skoropadskiego. Ukraińcy galicyjscy upatrywali sojusznika w białej armii gen. Denikina, natomiast Petlura, świadom nieprzychylne- 
powrotu do tradycji wielonarodowościowej Rzeczpospolitej Obojga Narodów, ale to trzydziestomilionowa Ukraina stanowiła kluczowy punkt przesądzający o równowadze sił w stosunku do Rosji ${ }^{14}$. Plany te spaliły jednak na panewce wraz z niemożnością porozumienia się z Litwą oraz fiaskiem akcji polsko-ukraińskiej w 1920 r. $^{15}$

Traktat ryski w ocenie większości badaczy i publicystów stanowił porażkę koncepcji federacyjnej Piłsudskiego, za co bezpośrednią odpowiedzialność miała ponosić delegacja polska negocjująca warunki pokoju. Jej główni przedstawiciele, Stanisław Grabski i Jan Dąbski, wywodzący się ze środowisk endeckich, mieli realizować inkorporacyjną strategię wschodnią Romana Dmowskiego, polegającą na ograniczeniu aspiracji terytorialnych dla uniknięcia zbyt dużej reprezentacji mniejszości narodowych w organizmie państwa polskiego. Czołowy przedstawiciel wileńskich konserwatystów i zwolennik polityki Naczelnika Państwa Stanisław Cat-Mackiewicz jednoznacznie oceniał konsekwencje dokumentu: $w$ danym wypadku chodzi mi tylko o podkreślenie niewatpliwego faktu, że polityka federacyjna zostata przez traktat ryski przekreślona, że istniata może jeszcze w literaturze, ale nigdy $w$ życiu realnym ${ }^{16}$.

Inną ocenę porozumienia przedstawił po latach Andrzej Nowak. Wskazywał on, że Piłsudski świadomie zgodził się na oddanie zajętego przez Wojsko Polskie Mińska, bo nie wiązał z nim już żadnych nadziei na wskrzeszenie idei federacyjnej. Marszałek miał być świadomy potencjału nowoczesnego nacjonalizmu, co powodowało konieczność korekty planów federacyjnych, a właściwie rezygnacji z koncepcji polsko-litewskich działań zmierzających do odrodzenia I Rzeczpospolitej ${ }^{17}$. Zderzenie koncepcji z rzeczywistością spowodowało próbę przesunięcia programowego centrum na relacje polsko-ukraińskie.

W tym przypadku również silniejsze okazały się narodowe aspiracje Ukraińców względem Lwowa i Galicji Wschodniej, choć z drugiej strony sojusz Piłsudskiego i atamana Symona Petlury ${ }^{18}$ z kwietnia 1920 r. pokazywał, że możliwe są wspólne akcje polityczno-wojskowe, a w interesie obu państw leży współdziałanie w walce o niepod-

go stanowiska Denikina wobec wolnej Ukrainy, wiązał nadzieje z sojuszem polsko-ukraińskim. Dwa odmienne projekty spowodowały fasadowość zjednoczenia ziem ukraińskich i faktyczną bezsilność Petlury. W tym samym czasie w Charkowie powstał marionetkowy rząd Ukraińskiej Socjalistycznej Republiki Radzieckiej (USRR). Zależny od Moskwy rząd USRR był stroną negocjacyjną w trakcie podpisywania traktatu ryskiego. Polskie uznanie dla rządu USRR oznaczało koniec kooperacji z URL. Z kolei Białoruś ogłaszająca niepodległość w ramach Białoruskiej Republiki Ludowej (BRL) była w pełni zależna od niemieckiej polityki. BRL nie została oficjalnie uznana przez mocarstwa, a jej nadzieje na niepodległość skończyły się wraz z klęską wojsk niemieckich. P. Łossowski, Ksztattowanie się państwa polskiego i walka o granice (listopad 1918 - czerwiec 1921), [w:] Historia dyplomacji polskiej (potowa X-XX w.), t. 4: 1918-1939, red. tenże, Warszawa 1995, s. 98.

14 A. Nowak, Historie politycznych tradycji..., s. 187.

15 Tamże, s. 201.

16 S. Cat-Mackiewicz, Historia Polski od 11 listopada 1918 do 17 września 1939, Kraków 2012, s. 197, Pisma wybrane.

17 A. Nowak, Historie politycznych tradycji..., s. 206-207.

1821 IV 1920 r. podpisano w Warszawie Umowę między rządem Rzeczypospolitej Polskiej a rządem Ukraińskiej Republiki Ludowej, dotyczącą m.in. ustalenia granic między państwami i uznania 
ległość Ukrainy. To ostatnie przekonanie miało później towarzyszyć członkom ruchu prometejskiego w ich działaniach na rzecz polsko-ukraińskiej kooperacji. Z uwagi na znaczącą siłę nacjonalizmów, sprzeciw polskiej opinii publicznej wobec dalszych działań wojennych na wschodnich terenach ${ }^{19} \mathrm{i}$ odmienną wizję przeciwników politycznych obozu piłsudczykowskiego próba zrealizowania wizji federacyjnej zakończyła się niepowodzeniem. Można stwierdzić, że mimo iż traktat ryski stanowił ostateczne przypieczętowanie klęski pomysłu federacyjnego, nie było to równoznaczne z całkowitą rezygnacją z przebudowy geopolitycznej regionu. Jak zauważył Marek Kornat, ruch prometejski byta kontynuacją i przedtużeniem idei federacyjnej ${ }^{20}$, chociaż poddano go zasadniczym korektom² ${ }^{21}$, uwspółcześniając wizję z lat 1917-1920.

\section{POPRZEDNICY MYŚLI PROMETEJSKIEJ}

Za głównego autora przedprometejskich koncepcji geopolitycznych uznaje się ks. Adama Jerzego Czartoryskiego, który po powstaniu listopadowym uwypuklił zagadnienie dekompozycji imperium rosyjskiego w oparciu o etnicznie odmienne ludy zamieszkujące carskie terytorium $^{22}$. Książę twierdzil, że Rosja, kierując się fatszywym patriotyzmem ${ }^{23}$

Dyrektoriatu za oficjalny organ władzy URL, a będącą de facto sojuszem politycznym. 24 IV $1920 \mathrm{r}$. podpisano konwencję wojskową, która oznaczała sojusz militarny wymierzony w Rosję.

$19 Z$ tego punktu widzenia najważniejsze byto to, czy spoteczeństwo polskie chce prowadzić taka ambitna, kosztująca wiele wysitku i nie zawsze dla wszystkich zrozumiata politykę bardzo dalekosiężna na Wschodzie, czy raczej chce się ograniczyć do obrony niepodlegtości i budowania struktur stabilnego, spokojnego życia. Pitsudski chciat kalkulować w kategoriach dekad czy nawet wieku, gdy zmęczone wojna spoteczeństwo myślato o przysztym miesiącu - tłumaczył w 2013 r. Andrzej Nowak. W jego ocenie we wrześniu 1920 r. nastąpiły masowe wystąienia Polaków wszystkich opcji, nie tylko socjalistów, ale narodowych demokratów, ludowców wszelkiej „maści” - za pokojem z Moskwą. Dominowato zmęczenie wojna, która w sumie trwata sześć lat. Wydawato się, że nadszedt wreszcie moment - po odpędzeniu bolszewików spod Warszawy, w którym można byto sobie urządzić wolna Polskę. [...] Pitsudski miat takie nastawienie, że on, wielki wódz, nakreśla dalekowzroczne wizje, a naród chce zadowolić się matym. Odepchnięto wroga i Pitsudski ma ręce związane: spoteczeństwo nie chce dalej walczyć, Ukraińcy, tak jak wcześniej Litwini, nie chca wspótpracowaí z Polska; można tylko zawrzeć pokój. Cytaty za: W 1920 r. w polskich domach nieustannie przewijato się hasto "musisz iść do wojska”, wywiad z Andrzejem Nowakiem, [online] http://www.portal.arcana.pl/W-1920-r-w-polskich-domach-nieustannie-przewijalo-sie-haslo-musisz-isc-do-wojska,4011.html, 12 IX 2013.

$20 \quad$ M. Kornat, Ruch prometejski..., s. 77.

21 Przejawem braku neutralności i wrogiej polityki Litwy wobec Rzeczpospolitej był traktat z Rosją zawarty 12 VII 1920 r. przyznający Wilno Litwie oraz wystąpienia wojsk litewskich przeciw Polakom w okolicach Wilna i na Suwalszczyźnie w lipcu i sierpniu tego samego roku. Taryba, czyli Litewska Rada Państwowa, która proklamowała niepodległość Litwy na początku 1918 r., nie zgadzała się na oddanie Polsce Wileńszczyzny i Suwalszczyzny, mimo etnicznej przewagi Polaków. Czołowi politycy Taryby, Antanas Smetona i Augustinas Voldemaras, nie akceptowali również wizji federacji Litwy z Polską. P. Łossowski, Ksztattowanie się państwa polskiego..., s. 150.

22 A. Nowak, Przez Ukrainę i Kaukaz na Petersburg: początek drogi do koncepcji prometejskich w polskiej myśli politycznej, [w:] Ruch prometejski..., s. 17-24.

Tamże, s. 23. 
podboju i panowania, zachowuje zaborczy instynkt. Stąd brało się przekonanie o niepohamowanym imperialnym dążeniu do podboju kolejnych terytoriów. Ekspansjonizm mógł być zatrzymany jedynie przez adekwatną reakcję „liberalnej” Europy, która w starciu z Rosją miała wysuwać postulat wsparcia etnicznych i wyznaniowych żywiołów zdominowanych przez carat.

Inny autor, publicysta i uczestnik powstania listopadowego, Maurycy Mochnacki, przypisywał kluczowe znaczenie w rozbijaniu imperium rosyjskiego Ukrainie, a powodzenie odbudowy niepodległej Polski uzależniał od tego, w którą stronę - polską czy rosyjską - zwróci się jej wschodni sąsiad ${ }^{24}$. Ten sposób postrzegania spraw regionu i jego wagi dla dziejów Europy celnie ujął Zygmunt Krasiński w Memoriale dla Napoleona III z 1854 r.: największa sita Rosji w jej stosunku do Europy nie jest ani w Moskwie, ani $w$ Petersburgu, ani $w$ Krymie, ale $w$ Kijowie, $w$ Wilnie i $w$ Warszawie ${ }^{25}$. Pogląd ten będzie później charakterystyczny dla czołowych przedstawicieli ruchu prometejskiego w II Rzeczpospolitej.

Konsekwencjami I wojny światowej były wybijanie się na niepodległość państw bałtyckich, walka o własny byt państwowy Ukrainy oraz emancypacja narodowa Kaukazu Północnego i Zakaukazia. W 1917 r. Finlandia proklamowała niepodległość, wkrótce to samo uczyniły Litwa, Łotwa i Estonia, niedługo później także Ukraina. W 1918 r. aspiracje niepodległościowe zgłosiły republiki Kaukazu - Gruzja, Azerbejdżan i Armenia ${ }^{26}$. Narody zamieszkujące te państwa, podobnie jak górale z Kaukazu Północnego skupieni wokół tzw. Rządu Górskiego, domagały się międzynarodowego uznania najpierw przez państwa centralne (w obawie przed rosyjską agresją), a po porażce tych ostatnich - przez państwa ententy ${ }^{27}$. Stosunek środowisk gruzińskich do sowieckiej Rosji obrazuje odpowiedź prezydenta Noego Żordanii na bolszewicką propozycję wspólnej walki z „białą” armią gen. Antona Denikina: Nasza droga idzie ku Europie, droga Rosji - ku Azji. Wiem, $i \dot{z}$ wrogowie powiedza, że jesteśmy stronnikami imperializmu. Dlatego to winienem zdecydowanie stwierdzić - przedktadam imperialistów Zachodu nad fanatyków Wschodu ${ }^{28}$.

$\mathrm{Na}$ tym jednak „potencjał prometejski” się nie kończył. W orbicie zainteresowań ruchu znajdowały się wszystkie grupy etniczne zgłaszające swoje prawo do niezależnego istnienia i rozwoju. Poza wyżej wzmiankowanymi narodami posiadającymi tradycje państwowe były to także pozbawione państwowej historii narody Kozaków dońskich i kubańskich, terskich, kałmyckich i astrachańskich, Tatarów krymskich i idel-uralskich oraz Turkiestańczyków, a na północy ludów Karelii i Ingermanlandii ${ }^{29}$. Tereny te razem wzięte stanowiły potencjalny etnograficzno-religijny punkt zapalny, który miała wykorzystać idea prometejska.

24 Zob. M. Mochnacki, Powstanie narodu polskiego w roku 1830 i 1831, oprac. i przedm. S. Kieniewicz, t. 1-2, Warszawa 1984.

25 Z. Krasiński, Pisma filozoficzne i polityczne, Kraków-Warszawa 1912, s. 553, Pisma, t. 7.

26 W. Materski, Kaukaz w polityce międzynarodowej 1917-1921, [w:] Ruch prometejski..., s. 127-136.

27 Tamże, s. 130.

28 Tamże, s. 132.

29 T. Schaetzel, Racja stanu Polski na wschodzie, „Pressje” 2010, nr 23, s. 100-119. 
Dezimperializacja Rosji znajdowała podatny grunt szczególnie na terenach Kaukazu, miejsca, w którym, według mitologii, tytan Prometeusz został przykuty do skały oraz gdzie znajdują się ważne źródła ropy naftowej, gazu i rudy manganu. Narody północnego Kaukazu i Zakaukazia, mimo różnic językowych, religijnych i historycznych, lączyła niechęć do północnego agresora, widoczna szczególnie w XIX w., kiedy to miejscowe elity polityczne rozbudzały i pogłębiały uczucia narodowe oraz integrowały obszary etniczne stanowiące dotąd amorficzny konglomerat dialektów, różnych zwyczajów i prowincjonalnych odrębności ${ }^{30}$. Postępująca unifikacja narodowych wartości, przy jednoczesnej europeizacji wzorców ustrojowych i scaleniu lokalnych odmienności, pozwoliła na stworzenie zbieżnej strategii krajów Kaukazu Południowego. Tworzyły ją kaukaska myśl niepodległościowa, która po wielu zmaganiach i zawiłościach otwarcie przyjęła zasadę pełnej niepodległości, oraz uznanie konfederacji kaukaskiej jako zasady realizacji idei niepodległości państw tego obszaru ${ }^{31}$. Oznaczało to, że pomimo różnic, także politycznych, i antagonizmów wewnątrz poszczególnych państw udało się osiągnąć pewną świadomość wspólnoty losu i, nie bez przeszkód, doprowadzić do wspólnego działania, np. w staraniach o międzynarodowe uznanie i dopuszczenie do paryskiej konferencji pokojowej ${ }^{32}$.

Z kolei o przychylnym nastawieniu miejscowych rządów do Polski może świadczyć wojskowa umowa polsko-gruzińska ${ }^{33}$ zawarta jeszcze w trakcie trwania wojny polsko-bolszewickiej ${ }^{34}$. I choć już w 1921 r. Rosji sowieckiej udało się pozbawić niepodległości wszystkie republiki kaukaskie, jasne stało się, że ich elity polityczne nie poprzestaną na emigracyjnej wegetacji ${ }^{35}$. Otwierało się tu naturalne pole do działania dla wszystkich zwolenników ruchu prometejskiego ${ }^{36}$.

30 W. Bączkowski, Uwagi o Kaukazie, [w:] tenże, O wschodnich problemach Polski..., s. 183-185.

31 Tamże, s. 185.

32 W. Materski, Kaukaz w polityce..., s. 132.

33 Polsko-gruziński sojusz wojskowy był wynikiem misji Tytusa Filipowicza, który po krótkich negocjacjach na przełomie kwietnia i maja 1920 r. sfinalizował umowę zawierającą program pomocy militarnej II RP dla armii gruzińskiej, wspólny plan operacyjny przeciwko Rosji oraz procedurę wymiany przedstawicieli dyplomatycznych i wojskowych po nawiązaniu oficjalnych stosunków dyplomatycznych. Sowieci zdołali jednak na początku 1921 r. zająć republiki kaukaskie, niwecząc tym samym wykorzystanie aliansu. Mimo to sojusz stanowił wsparcie zarówno natury dyplomatycznej, jak i moralnej, był także podstawą dalszej współpracy z Gruzinami (np. gruzińscy oficerowie kontaktowi w Wojsku Polskim). Tamże, s. 135-136.

34 Tamże, s. 135.

35 M. Kornat, W kregu ruchu prometejskiego. Związek Zbliżenia Narodów Odrodzonych (1921-1923) i Instytut Wschodni w Warszawie (1925-1939), „Politeja” 2004, nr 2, s. 351.

36 Oczywiście nie oznacza to, że w gruzińskich elitach politycznych nie występowały różnice i antagonizmy dotyczące sposobu postrzegania ówczesnej sytuacji ojczyzny, roli zachodnich polityków czy wagi idei prometejskich. W literackiej formie interesująco przedstawił je Ksawery Pruszyński. Zob. K. Pruszyński, Trzynaście opowieści, Warszawa 1995, s. 231-262. 


\section{SPOSÓB POSTRZEGANIA ROSJI CARSKIEJ I SOWIECKIEJ}

Zasadnicze znaczenie dla zrozumienia idei prometejskiej mają sposoby, w jakich propagatorzy ruchu ujmowali problem rosyjskiego imperializmu, który w nowej, ideologicznej szacie bolszewizmu ${ }^{37}$ nabrał jeszcze większej, rewolucyjnej dynamiki. Prometeizm był jednym z następstw konstatacji marszałka Piłsudskiego: byt $i$ istnienie Polski, takiej, jaka posiadamy, nie sa zupetnie pewne ${ }^{38}$. W listopadzie 1926 r., podczas posiedzenia Komitetu Obrony Państwa, Piłsudski precyzował źródło głównego niebezpieczeństwa: Ludzie niespokojni w Rosji będa nas szukać, bo Rosja w stosunku do nas może dochodzić swego rewanżu [...]. Na razie bolszewicy pracuja nad rozktadem wewnętrznym naszego państwa i jest to ich stata praca ${ }^{39}$.

Bardzo silną, konstytutywną cechą wszystkich prometeistów było owo uwrażliwienie na sprawę rosyjskiej ekspansji. Bączkowski dostrzegał w Rosji radzieckiej wyraźną przewagę pierwiastka azjatyckiego ${ }^{40}$, co miało się jego zdaniem przejawiać m.in. w podszytym mistycyzmem materializmie światopoglądowym Rosjan, trwałej niezdolności do poświęcenia życia w walce o ideały narodowe lub państwowe czy wreszcie odmiennej filozofii wojny, która nie rozstrzygała się w walnej bitwie czy manewrach taktyczno-operacyjnych, ale za pomocą wcześniejszej, rozkładowej pracy wewnątrz wrogich

37 Termin „bolszewicy” został po raz pierwszy użyty w 1903 r. na II Zjeździe Socjaldemokratycznej Partii Robotniczej Rosji (SDPRR) i oznaczał grupę członków partii uznającą się za większość (ros. bolszynstwo) w przeciwieństwie do mniejszości (ros. mienszynstwo). Przywódcą tego odłamu był Włodzimierz Lenin, nawołujący do centralizowania i dyscyplinowania partii, której mieli przewodzić zawodowi rewolucjoniści. Popularność i szerszy rozgłos bolszewicy zyskali w trakcie rewolucji 1905-1907 w Rosji, kiedy to pod hasłami demokratyzacji i przodownictwa proletariatu dążyli do obalenia carskiego ustroju. Po rewolucji lutowej 1917 r. zaczęli agitować na rzecz władzy proletariatu oraz, pozostając w opozycji do mienszewików i eserowców (o których będzie mowa w dalszej części tekstu), bolszewizować Rady. W październiku tego samego roku obalili Rząd Tymczasowy, przejmując władzę w Rosji. Zob. R. Pipes, Rosja bolszewików, przeł. W. Jeżewski, Warszawa 2005.

Wielka deklaracja Marszatka Pitsudskiego, „Głos Prawdy” 1926, nr 129 (27 II), s. 119, [cyt. za:] M. Kornat, Ruch prometejski..., s. 83.

39 Protokót pierwszego posiedzenia Komitetu Obrony Państwa z dnia 23 listopada 1926 r., oprac. P. Stawecki, „Kwartalnik Historyczny” 1988, nr 3, s. 83.

Samuel Huntington, opisując cywilizację prawosławną, której ośrodkiem jest Rosja, zwracał uwagę na cechy odróżniające ją od zachodniego chrześcijaństwa: [...] bizantyjski rodowód, odrębna religia, dwieście lat panowania tatarskiego, biurokratyczny despotyzm, oraz ograniczony kontakt $z$ Renesansem, Reformacja, Oświeceniem i innymi zjawiskami tak ważnymi dla Zachodu. S. P. Huntington, Zderzenie cywilizacji i nowy ksztatt taduświatowego, przeł. H. Jankowska, Warszawa 2004, s. 56, Spectrum. W kontekście omawianych powyżej różnic cywilizacyjnych i religijnych między Wschodem a Zachodem, znajdujących wyraz także w imperialnej polityce carskiej Rosji, warto przytoczyć również słowa francuskiego filozofa Alaina Besançona: Petersburscy cesarze usunęli wszystkie te staroruskie czynniki, które miaty charakter „swięty”, przede wszystkim zaś mesjanistyczny zamiar odbudowy prawdziwego chrześcijaństwa uniwersalnego. Zachowali jednak dwie rzeczy: wtadze absolutna oraz inny mesjanizm, o charakterze niereligijnym: panowania nad nieograniczonym terytorium. Rosyjski imperializm, czy też raczej gigantyczne terytorium, które to państwo zajmuje, stat sie gtówna wartościa transcendentna, jaka zaproponowano narodowi rosyjskiemu. A. Besançon, Święta Ruś, przeł. Ł. Maślanka, Warszawa 2012, s. 49, Biblioteka Teologii Politycznej, t. 6. 
państw. Ten, jak twierdził redaktor „Biuletynu Polsko-Ukraińskiego”, specyficzny rodzaj akcji wojennej wynikał z innego niż europejski rozłożenia akcentów: Gtównym rodzajem broni rosyjskiej, decydującym o dotychczasowej trwatości Rosji, jej sile i ewentualnych przysztych zwyciestwach, nie jest normalny w warunkach europejskich czynnik sity militarnej, lecz gtęboka akcja polityczna, nacechowana treścia dywersyjna, rozktadowa ipropagandowa ${ }^{41}$.

Ta odmienność, co ważne, miała brać się z pustki kulturowej Rosji, z jej dziejów silnie naznaczonych wpływami mongolskimi: Brak silnych wptywów tacińskiego Zachodu ina wpót orientalny wptyw rychto upadającego Bizancjum wytworzyty pewna pustkę kulturalna Moskwy, której nie zdotat wypetnić po brzegi odlegty Wschód Indii i Chin. Pustke te poczęta wypetniać samoczynna twórczość kulturalna Moskwy, idąca po linii nadanej przez impuls wspaniatej, olbrzymiej, jakkolwiek mocno mechanicznej kultury hiperimperium Czingiza i Tamerlana ${ }^{42}$.

W takiej optyce prometeizm stał się instrumentem w walce o poszerzenie cywilizacji zachodniej na Wschód. To przekonanie o znaczeniu Rzeczpospolitej jako cywilizacyjnej siły, jako fragmentu większej, zachodnio-łacińskiej całości, w walce z jeśli nie barbarzyńską, to odmienną kulturą azjatycką znajdowało wyraz także w opiniach innych członków ruchu. Socjalista Tadeusz Hołówko, orędownik przychylnej wobec Kresów polityki i czołowy prometeista, w swoich sejmowych wystąpieniach wprost stawiał znak równości pomiędzy mocarstwową ambicją Polski, jej polityką wobec Kresów i wyzwaniem dokonania wielkiej cywilizacyjnej pracy ${ }^{43}$. Zdaniem tego zaufanego współpracownika Naczelnika Państwa i przez pewien czas szefa Wydziału Wschodniego MSZ granica polsko-sowiecka miała być cywilizacyjną cezurą zachodniej Europy. Przekonaniu o kulturowo-wolnościowej misji Rzeczpospolitej towarzyszyła obserwacja ruchów narodowościowych i ich ambicji niepodległościowych.

Główne działania prometeizmu budowano wokół tezy o nieuchronności rozpadu Związku Sowieckiego właśnie pod wpływem rozbudzonych i napierających tendencji narodowowyzwoleńczych. Uznawano, że dotychczasowy model wielonarodowościowego imperium Wschodu jest nie tylko niebezpieczny dla Polski, ale wręcz anachroniczny. Kolejny ważny reprezentant prometeizmu, znawca spraw narodowościowych Leon Wasilewski, przekonywal, że ruchy narodowe posiadają pewnego rodzaju żywiotowość. Raz wszczęte, nie daja sie już zniszczyć i dąża - wbrew wszystkiemu - do ideatu niepodlegtościpaństwowej, która realizuja w warunkach ostabienia wtadzy centralnej, spowodowanego bądź wewnętrzna, bądź zewnętrzna katastrofą państwa wielonarodowego ${ }^{44}$.

By nacjonalizmy te odgrywały pożądaną dla polskiej racji stanu rolę, należało wyzbyć się jednostkowego myślenia czy, jak to określił redaktor pierwszego periodyku pro-

$41 \quad$ W. Bączkowski, Uwagi o istocie..., s. 132-133.

42 Tamże, s. 117.

43 Tadeusz Hotówko o demokracji, polityce i moralności życia publicznego, wstęp, wybór i oprac. A. Chojnowski, Warszawa 1999, s. 263.

44 L. Wasilewski, Polityka narodowościowa Sowietów, „Przegląd Polityczny” 1925, nr 5-6, [w:] tenże, Drogiporozumienia. Wybórpism, wybór, wstęp i przyp. B. Stoczewska, Kraków 2001, s. 130, Biblioteka Klasyki Polskiej Myśli Politycznej, t. 6. 
metejskiego „Przymierze” Włodzimierz Wakar, matostkowego maksymalizmu narodo$w e g o^{45}$. Prometeizm nie był jednak programem minimalistycznego dostosowania grup odrębnych etnicznie do państwowego interesu polskiej większości. Kwestia narodowościowa miała dwa komplementarne wobec siebie uzasadnienia. Pierwsze odwoływało się do nieodzowności wyposażenia państwa w program działania na wypadek głębokich, fundamentalnych zmian w ustroju ZSRS ${ }^{46}$. Było oczywiste, że wobec zmian zarysowujących się na horyzoncie Rzeczpospolita nie może pozostawać obojętna ${ }^{47}$. Drugie, ofensywne założenie miało źródło w filozofii politycznej decydentów II RP, w ich głębokim przekonaniu o znaczącym potencjale zarówno Rzeczpospolitej jako organizmu kulturowo-politycznego, jak i samej akcji prometejskiej jako realistycznej odpowiedzi na wyzwania nowoczesności. Te kanony myślenia o polskości i własnej państwowości znajdowały wyraz w postulatach dotyczących polityki wobec Kresów: zatożeniem tego programu powinno być dążenie, żeby Kresy te na zawsze zwiąać z państwowościa polska, uczynić z nich integralna czesśc. Uczynić to można tylko na tej drodze, że ludność Kresów dobrowolnie duchowo zespoli się z pañstwowościa polska, poczuje się obywatelami polskimi $z$ wtasnej woli i przekonania ${ }^{48}$.

Dostrzegano także aspekt zewnętrzny, dotyczący postępujących przeobrażeń w świadomości społecznej narodów: mocarstwowy interes Polski nakazuje, przeciwnie, szukać sposobów, aby te marzenia urzeczywistniaty się nie przeciw Polsce, lecz w zgodzie zniq i w oparciu o niq ${ }^{49}$.

ZSRS nie pozostawał obojętny na aktywność polskiego wywiadu i całego ruchu prometejskiego. Bolszewicy prowadzili własną politykę narodowościową. Jak zauważał Leon Wasilewski, komuniści rosyjscy początkowo opowiadali się za prawem do samookreślenia narodów, co było zgodne z ideologią międzynarodowego ruchu socjalistycznego. Jednak z czasem, gdy bolszewicy zdołali zdobyć władzę, przesłanie musiało ulec zmianie i odtąd na sztandarach wywieszano hasło samookreślenia mas pracujacych ${ }^{50}$. Owa emancypacyjna akcja propagandowa z racji istnienia przeciwników politycznych i społecznych (m.in. mieńszewicy, Bund ${ }^{51}$, masy chłopskie) ulegała ciągłemu zawęże-

45 M. Kornat, $W$ kregu ruchu prometejskiego..., s. 354.

46 Tenże, Ruch prometejski..., s. 83.

47 L. Wasilewski, Wnioski koniunkturalne, „Biuletyn Polsko-Ukraiński” 1933, nr 24, [w:] tenże, Drogi porozumienia..., s. 183-186.

48 Tadeusz Hotówko o demokracji..., s. 127.

49 L. Wasilewski, Sprawa kresów wschodnich, „Droga” 1924, nr 5, [w:] tenże, Drogi porozumienia..., s. 115 .

50 Tenże, Polityka narodowościowa..., s. 128.

51 Mienszewicy (z ros. mienszynstwo - mniejszość) - frakcja rosyjskiej partii socjaldemokratycznej przeciwna rewolucyjnemu programowi bolszewików Lenina. Mienszewicy jako zwolennicy ewolucyjnych przemian społecznych wspierali Rząd Tymczasowy powstały po rewolucji lutowej 1917 r. Po bolszewickiej rewolucji październikowej czołowi przedstawiciele mieńszewików znaleźli się na emigracji. Bund (właśc. Powszechny Żydowski Związek Robotniczy) był żydowską partią socjalistyczną powstałą w 1897 r. w Wilnie w celu obrony interesów żydowskich robotników w Rosji. Od 1918 r. działał także w Polsce; współpracował z PPS bądź z komunistami (lata 1933-1935), niezmiennie głosząc hasła antysyjonizmu, przebudowy społecznej oraz żydowskiej autonomii kulturowo-narodowej 
niu, stając się odwróceniem wcześniejszego przesłania: tak więc w ostatecznym wyniku samookreślenie narodów zostato w praktyce zastąione przez „samookreślenie” narodowe urzędowej partii komunistycznej, rządzacej faktycznie Zwiąkiem i wszystkimi jego autonomicznymi częściami $[\ldots]^{52}$.

Integralny dla akcji prometejskiej antykomunizm nie był jedyną cechą przeciwną narodowościowej taktyce ZSRS. Kluczowym elementem działań sowieckich wobec mniejszości były pozory swobody językowej i oświatowej, które miały prowadzić do stworzenia sztucznego tworu: „narodu sowieckiego” ${ }^{33}$. Polityka taka w rzeczywistości wzmacniała centralizm sowiecki, pozbawiając narody ukraiński i kaukaskie szans na artykułowanie własnych aspiracji ${ }^{54}$. Bardziej niebezpieczną z polskiego punktu widzenia okolicznością było wszczęcie przez bolszewików działań określonych przez jednego ze współczesnych badaczy ruchu mianem prometeizmu à rebours ${ }^{55}$.

Po międzynarodowym uznaniu w 1923 r. ${ }^{56}$ wschodniej granicy Polski komuniści, wykorzystując narzędzia propagandowe i oczywiste wpływy w rządzie Ukraińskiej Socjalistycznej Republiki Radzieckiej, starali się przekonać ukraińską mniejszość w Polsce o niekorzystności tej sytuacji, o nieporównanie większych swobodach w ZSRS i pilnej potrzebie zmian geopolitycznych. Towarzyszył temu wysiłek wywiadowczy, którego świadectwem stały się skuteczne prowokacje Głównego Zarządu Wywiadowczego w ramach akcji „MOR-trust”, która poprzez fikcyjne organizacje monarchistyczne miała ujawniać działaczy narodów prometejskich ${ }^{57}$. Także w tej działalności sowieckich służb znajduje się przyczyna podjęcia działań prometejskich. Była to kwestia ściśle związana z bezpieczeństwem narodowym i koniecznością zabezpieczenia integralności terytorialnej państwa ${ }^{58}$.

Na tym geopolitycznym tle kształtowała się klasyczna prometejska konstatacja: Niepodlegtość Polski nie da siępomyślećbez niepodlegtości Litwy, Łotwy, Estonii, Finlandii,

w polskim państwie. W trakcie II wojny światowej partia ta współpracowała z Radą Pomocy Żydom oraz Delegaturą Rządu na Kraj. Członkowie Bundu, obok przedstawicieli prawicowego Żydowskiego Związku Wojskowego, wzięli udział w powstaniu w getcie warszawskim w 1943 r. Zob. R. Pipes, Rosja bolszewików...

L. Wasilewski, Polityka narodowościowa..., s. 128.

M. Kornat, $W$ kregu ruchu prometejskiego..., s. 383.

L. Wasilewski, Polityka narodowościowa..., s. 129.

J. J. Bruski, W trójkącie Warszawa-Paryż-Praga. Reaktywacja wspótpracy polsko-ukraińskiej 1925-1926, [w:] Ruch prometejski..., s. 106.

5615 III 1923 r. podpisano dodatkowy protokół do traktatu wersalskiego zatwierdzający wschodnią granicę II Rzeczpospolitej, potwierdzający przynależność Galicji Wschodniej i Wileńszczyzny do terytorium II RP. Uznanie wschodnich granic kraju przez mocarstwa zachodnie, do których w kwietniu 1923 r. przyłączyły się Stany Zjednoczone, zostało ustanowione wbrew woli ZSRS i Litwy. Na decyzję Rady Ambasadorów miały wpływ dobre relacje Polski z Francją, której zależało na wsparciu w sprawie okupacji Zagłębia Ruhry, a także z Włochami. Ponadto Litwa w styczniu tegoż roku zajęła mający status neutralnego port w Kłajpedzie. P. Łossowski, Ksztattowanie siępaństwa polskiego..., s. 215.

57 A. Wszendyrówny, Ekspozytura Nr 2 Oddziatu II Sztabu Gtównego Wojsk Polskiego, [w:] Ruch prometejski..., s. 173.

58 M. Kornat, Idea prometejska..., s. 56. 
Ukrainy i Biatorusi ${ }^{59}$. Poza tym silnym węzłem ontologiczno-egzystencjalnym ważnym czynnikiem kształtowania relacji był stosunek państwa polskiego do sąsiednich narodów. Z jednej strony Polska nie planowała wsparcia ewentualnych działań zbrojnych prowadzonych przez któryś z „narodów prometejskich”, by nie naruszyć ustaleń traktatu ryskiego ${ }^{60}$. Po zamachu majowym 1926 r. zapewniała sowieckie kierownictwo, że zachowanie status quo na wschodniej granicy Rzeczpospolitej pozostaje ciągłą wykładnią polskiej polityki zagranicznej. $Z$ drugiej strony jednoznacznie uwidaczniał się status Polski jako regionalnego lidera, geograficznie i historycznie predestynowanego do bycia „Prometeuszem wschodu”. Sprzyjał temu brak imperialno-kolonialnych tradycji ${ }^{61}$. Zdaniem Schaetzela, ten stosunek Polski na Wschodzie do narodów wyzwolonych i wyzwalajacych się, narzucajacy Polsce tak znamienna role dziejowa, predestynuje ją do mocarstwowego stanowiska w znaczeniu jak najbardziej niezaborczym ${ }^{62}$.

\section{ORGANIZACJE RUCHU PROMETEJSKIEGO}

Możliwie wyczerpujące opisanie historii ruchu prometejskiego w II Rzeczpospolitej wymaga rozdzielenia dwóch szeroko rozumianych sposobów wprowadzania w życie ideałów prometejskich w polityce zagranicznej II RP. Z jednej strony prometeizm był działalnością par excellence taktyczno-operacyjną. Wspomniana wcześniej funkcja obronno-dywersyjna realizowana była przede wszystkim przez działalność wywiadu wojskowego, czyli II Oddziału Sztabu Głównego (wcześniej Sztabu Generalnego) Wojska Polskiego ${ }^{63}$. Nieodzownym elementem prometeizmu była też rozbudowana infrastruktura instytucjonalna, odpowiedzialna za kształcenie polskich elit w zakresie nauk o Wschodzie. Miało ono dokonywać się poprzez gruntowne poznawanie kultur, społeczeństw i języków państw leżących za wschodnią granicą II RP, wydawanie gazet ${ }^{64}$ przybliżających polskiej opinii publicznej skomplikowane zagadnienia narodowościowe i geopolityczne, wreszcie budowanie platformy porozumienia w kręgu kół emigracyjnych, niejednokrotnie zantagonizowanych ${ }^{65}$.

59 Cyt. za: J. Łojek, Idea federacyjna Józefa Pitsudskiego, „Libertas. Kwartalnik Społeczno-Polityczny” 1986, nr 6, s. 56.

60 M. Kornat, Idea prometejska..., s. 58.

61 T. Schaetzel, Racja stanu..., s. 102-103.

62 Tamże, s. 104.

63 A. Wszendyrówny, Ekspozytura Nr 2..., s. 171-186.

64 Do organów prasowych ruchu prometejskiego należały: tygodnik „Przymierze”, wydawany w Paryżu miesięcznik „Le Prométhée”, kwartalnik „Wschód Orient”, „Biuletyn Polsko-Ukraiński”, kwartalnik „Problemy Europy Wschodniej”, dwutygodnik „Myśl Polska” czy też czasopismo „Daleki Wschód”. M. Kornat, W kregu ruchu prometejskiego..., s. 350-354.

65 Grupy emigracji prometejskiej często tworzyły przeciwne obozy. Przeciwnikami wspieranych przez Polskę gruzińskich socjaldemokratów Ramiszwilego i kaukaskich górali Saida Szamila byli politycy narodowej demokracji skupieni wokół Aleksandra Assatianiego, górale kaukascy Haidara Bammata czy, w późniejszym okresie, zwolennicy ormiańskiego działacza Arszaka Dżamaliana. Wśród artyku- 
Nie mniej istotną kwestią było pozyskanie i wsparcie emigracyjnych przywódców politycznych, zapewnienie im dostępu do ośrodków naukowych i możliwości publikacji własnych tekstów. Tego rodzaju środki pozwalały na lepsze poznanie opinii elit politycznych narodów prometejskich, tworzyły też poczucie wsparcia i solidarności. Przede wszystkim jednak chciano uniknąć sprowadzenia kwestii prometejskiej do ordynarnej dywersji za pieniądze, jak to określił senator Stanisław Siedlecki, jeden z czołowych twórców „Przymierza”"66.

W 1921 r., z inicjatywy środowiska skupionego wokół Piłsudskiego, powstała organizacja o nazwie Związek Zbliżenia Narodów Odrodzonych (ZZNO). Zrzeszała ona przedstawicieli Finów, Estończyków, Litwinów, Białorusinów, Ukraińców, Tatarów krymskich, Kozaków kubańskich, Gruzinów, Azerów i górali Kaukazu Północnego ${ }^{67}$. W ramach Związku powstała Sekcja Polska, a intensywną ideową pracę podjęli przede wszystkim Włodzimierz Wakar, Tadeusz Hołówko i Tadeusz Schaetzel. Organem prasowym instytucji stało się „Przymierze”, w którym czołowi prometeiści publikowali swoje koncepcje polityki wschodniej, narodowościowej i projekty geopolitycznej przebudowy regionu. Na łamach pisma proponowano główne cele polityki wschodniej, czyli wolność Ukrainy, niepodległość Litwy i niezależność Białorusi ${ }^{68}$. Wśród czołowych autorów znaleźli się m.in.: Siedlecki, Hołówko, Wakar i Antoni Bolesław Dobrowolski.

Związek aktywnie działał na rzecz umożliwienia skutecznej współpracy kół emigracyjnych, których członkowie mieli w przyszłości stanowić naturalną warstwę inteligencką aspirującą do przywództwa politycznego. Członkowie ZZNO zabiegali o ich możliwie najbardziej propolskie stanowisko, o stworzenie świadomości wspólnoty losu, wreszcie o to, by Rzeczpospolita traktowana była przez nich jako konsekwentny protektor ${ }^{69}$.

Do kryzysu w funkcjonowaniu ZZNO doszło już w czerwcu 1921 r., a jego bezpośrednim powodem było objęcie przez Konstantego Skirmunta teki ministra spraw zagranicznych. Polityk ten był związany z dawnym Komitetem Narodowym Polskim (KNP) w Paryżu, a zatem jego wizja stosunków polsko-sowieckich była zasadniczo odmienna od prometejskiej ${ }^{70}$. Za nierealistyczne uważał nadzieje na emancypację narodów

łowanych wobec nich zarzutów najważniejsze dotyczyły fasadowości ugrupowań wspieranych przez II RP (nie reprezentowały woli narodu, istniały jedynie dzięki wsparciu Polski), braku radykalnych haseł narodowowyzwoleńczych, potajemnego sprzyjania Rosji i dyskryminowania oficerów o odmiennych poglądach. P. Libera, Ewolucja ruchu prometejskiego w okresie międzywojennym, [w:] Ruch prometejski..., s. 230-232.

A. Grzywacz, G. Mazur, Ruch prometejski w Polsce, „Zeszyty Historyczne” 1994, nr 110, s. 77-78.

M. Kornat, $W$ kregu ruchu prometejskiego..., s. 353.

Tamże, s. 354 .

69 Tamże.

70 Roman Dmowski, który był założycielem KNP, w czasie I wojny światowej za sojusznika, przy którego boku będzie można odbudować niepodległą Rzeczpospolitą, uznawał ententę. Reprezentował więc taktykę przeciwną wobec programu Józefa Piłsudskiego, który wiązał nadzieje z państwami centralnymi. Koncepcje te były rezultatem głębszych poglądów o charakterze geopolitycznym. Odmienne wizje ujawniły się już w trakcie odzyskiwania niepodległości, kiedy to uwaga Dmowskiego koncentrowała się wokół zachodniej, etnicznie polskiej granicy z Niemcami, zaś Piłsudski za główną oś politycznego działania Polski uznawał granicę wschodnią i walkę z Rosją. Dmowski uważał, że nawiązanie pokojo- 
ZSRS i wiązanie z tym długofalowych programów polskiej polityki wschodniej. Jego zdaniem aktywność polskiej dyplomacji winna była koncentrować się na normalizacji stosunków z Rosją sowiecką, których nie należało poświęcać na rzecz idealistycznych, emancypacyjnych i wielonarodowościowych wizji prometejskich ${ }^{71}$. Takie poglądy kierownika MSZ, wraz z odejściem Piłsudskiego ze stanowiska szefa Sztabu Generalnego, sprawiły, że ruch prometejski stracił niezbędne, instytucjonalne wsparcie. ZZNO został zawieszony i de facto zakończył działalność w 1923 r.

Doszły do tego wcześniejsze, niepomyślne z perspektywy idei prometejskich, działania wiceministra spraw zagranicznych Jana Dąbskiego. 7 października 1921 r. podpisał on z Lwem Karachanem, sowieckim przedstawicielem dyplomatycznym w Warszawie, umowę, która przewidywała wydalenie z Polski czternastu reprezentantów politycznej i wojskowej emigracji narodów białoruskiego i ukraińskiego ${ }^{72}$. W gronie tym znaleźli się m.in. Borys Sawinkow, Stanisław Bułak-Bałachowicz i Symon Petlura, uznani przez kierownictwo sowieckie za groźnych przeciwników. Taka decyzja postawiła polskich prometeistów w dwuznacznej sytuacji - wolnościowe i solidarnościowe postulaty zderzyły się z faktami wytworzonymi przez polityków afirmujących inne koncepty geopolityczne.

Wydalenie emigracyjnej elity prowadziło urzędników Wydziału Wschodniego MSZ albo do prób nieścisłych tłumaczeń takiego postępowania i powtarzania tezy o powrocie emigrantów w chwili niewypełniania przez Rosję postanowień traktatu ryskiego, albo do dyskretnego wspierania zarówno środowisk na wychodźstwie, jak i równoległego rozwoju stosunków gospodarczych z rządami sowieckich republik ${ }^{73}$.

Należy również pamiętać, że mimo niesprzyjających okoliczności część zwolenników prometeizmu jeszcze przed $1926 \mathrm{r}$. zapewniła sobie wpływy w MSZ. Byli to m.in.: Juliusz Łukasiewicz (w latach 1922-1926 naczelnik Wydziału Wschodniego), Roman Knoll, Wacław Jędrzejewicz, Schaetzel, Hołówko ${ }^{74}$. Co więcej, już w latach 1924-1925 podjęto działania na rzecz głębszej współpracy narodów kaukaskich z Polską. Polski poseł w Ankarze Roman Knoll, przy wsparciu attaché płk. Schaetzela, zabiegał o poszerzenie politycznego przedstawicielstwa w Związku Oswobodzenia Kaukazu ${ }^{75}$, przekonywał Turcję do pomysłu poparcia wysiłków narodowowyzwoleńczych społeczeństw Kaukazu, a także starał się pozyskać z polskiego ministerstwa większe dotacje dla kaukaskiej konfederacji.

Warto zaznaczyć, że w omawianym okresie nie wszyscy ministrowie spraw zagranicznych sceptycznie oceniali szanse powodzenia idei prometejskiej. Maurycy Klemens Zamoyski, kandydat prawicy, z ramienia Związku Ludowo-Narodowego, na

wych stosunków z Rosją będzie sprawdzianem naszej wartości politycznej, naszej zdolności do kierowania losami wtasnego państwa. R. Dmowski, Polityka polska i odbudowanie państwa, Warszawa 1925, s. 501.

71 Tamże, s. 358.

72 H. Bartoszewicz, Prometeizm Romana Knolla, [w:] Ruch prometejski..., s. 162.

73 M. Kruszyński, Wydziat Wschodni Ministerstwa Spraw Zagranicznych a idea rozbicia Rosji Radzieckiej w latach dwudziestych XX wieku, [w:] Ruch prometejski..., s. 152-156.

74 M. Kornat, Ruch prometejski..., s. 80.

75 Organizacja zrzeszająca osiadłych w Turcji emigrantów z Azerbejdżanu, Gruzji i Kaukazu Północnego. 
urząd Prezydenta RP w 1922 r., polityk związany z KNP i dawny działacz Stronnictwa Narodowo-Demokratycznego, pisał w instrukcji skierowanej do Knolla w 1924 r.: $z a$ sadniczym interesem polityki polskiej $w$ tym względzie jest skierowanie dążen tureckich w kierunku rozwoju samodzielności ludów mahometańskich oraz państw kaukaskich. Polska powinna przy tym być uważana w Turcji i w krajach muzutmañskich Rosji jako pewnego rodzaju patronka i ostoja moralna ich dążen wyzwoleńczych ${ }^{76}$.

Nie zmienia to generalnej oceny kryzysu ruchu prometejskiego w latach poprzedzających zamach majowy, znajdującej odzwierciedlenie choćby w polskim uznaniu Gruzińskiej Republiki Socjalistycznej czy też braku poparcia dla powstania w Gruzji w 1924 r. Widać jednak, że kierownictwo MSZ nie było całkowicie odporne na aktywność polskich dyplomatów zajmujących wysokie stanowiska i wykazujących się znajoością spraw wschodnich. Należy też podkreślić determinację, z jaką bliscy współpracownicy Piłsudskiego podejmowali dalsze starania - mimo różnic programowo-partyjnych, wewnętrznej niestabilności polskiego systemu politycznego oraz wydarzeń w polityce międzynarodowej, których symbolem stała się sowiecko-niemiecka umowa międzynarodowa z 1922 r., znana jako układ w Rapallo ${ }^{77}$.

W budowę sieci sojuszniczej między Polską a środowiskami kaukaskimi i ukraińskimi zaangażowano również Hołówkę. W lipcu 1925 r. doszło więc do sytuacji znamiennej: Knoll, Schaetzel i Hołówko wspólnie ustalali kontynuację wysiłków prometejskich, skoncentrowanych wokół reorganizacji emigracji ukraińskiej, stworzenia jednolitego ośrodka politycznego, łączności z krajem oraz zrealizowania finansowej i propagandowej pomocy dla akcji zjednoczeniowej polityków ukraińskich ${ }^{78}$. Wszystko to działo się przy akceptacji polskiego MSZ, co w rezultacie pozwoliło Hołówce na stworzenie w grudniu 1925 r. w Paryżu organizacji Le Prométhée (Prometeusz), w której skład weszli politycy ukraińscy, gruzińscy, azerscy i turkmeńscy oraz przedstawiciele Gorców, Tatarów krymskich i kazańskich ${ }^{79}$.

Rok 1925 przyniósł także powołanie do życia Instytutu Wschodniego w Warszawie. Placówka ta, początkowo ograniczająca się do prowadzenia nauki języków wschodnich i dalekowschodnich, wyrosła z potrzeby wykształcenia kompetentnej grupy urzędników zajmujących się wschodnim odcinkiem polskiej polityki zagranicznej ${ }^{80}$. Instytut pełnił funkcję ośrodka eksperckiego, dostarczając różnego rodzaju raporty i opracowania Wydziałowi Wschodniemu MSZ i Oddziałowi II Sztabu Generalnego.

Prawdziwym przełomem dla idei prometejskiej okazał się zamach majowy w 1926 r., przeprowadzony przez otwarcie sprzyjającego ruchowi prometejskiemu

76 Cyt. za: H. Bartoszewicz, Prometeizm Romana Knolla..., s. 164.

77 Układ w Rapallo zawarto 16 IV 1922 r. Dokument zawierał rezygnację sygnatariuszy z wszelkich roszczeń wynikających z I wojny światowej oraz przywracał stosunki dyplomatyczne i konsularne między dwoma państwami. Rapallo stało się z czasem synonimem polityki porozumienia między Rosją radziecką a III Rzeszą, ponad porządkiem międzynarodowych instytucji.

78 H. Bartoszewicz, Prometeizm Romana Knolla..., s. 167.

79 I. Werschler, Tadeusz Hotówko. Życie i dziatalność. Z dziejów obozu belwederskiego, Warszawa 1984, s. 218-221.

$80 \quad$ M. Kornat, $W$ kregu ruchu prometejskiego..., s. 368. 
Piłsudskiego. W pomajowej Polsce doszło do rozkwitu zaplecza instytucjonalnego ruchu. W 1928 r. utworzony został Klub „Prometeusz” w Warszawie, skupiający Ukraińców, Azerów, Gruzinów, górali Kaukazu Północnego, Turkiestańczyków, Karelczyków, Ingermanlandów i Wolnych Kozaków ${ }^{81}$. Jego placówki utworzono w Paryżu, Helsinkach i Hrabinie. Rozpędu nabrały działania Oddziału II - w jego ramach powstała „prometejska” Ekspozytura nr 2. Pojawiły się także dotacje finansowe z nowo utworzonego funduszu „N”. Miały one służyć m.in. rozwijaniu akcji prometejskiej oraz pomocy odpowiednim instytucjom i organom prasowym ruchu ${ }^{82}$. Za inne placówki prometejskie można uznać Ukraiński Instytut Naukowy w Warszawie prowadzony przez Romana Smal-Stockiego oraz Instytut Badań Spraw Narodowościowych Leona Wasilewskiego.

Istotną cezurą w ewolucji instytucjonalnego wymiaru ruchu prometejskiego było powołanie do życia w 1928 r. Orientalistycznego Koła Młodych. Grupa ta, działająca pod patronatem Instytutu Wschodniego, miała za zadanie przede wszystkim integrację i porozumienie z reprezentantami młodej generacji emigracji narodów zniewolonych, a także pozyskiwanie dla sprawy prometejskiej młodzieży polskiej ${ }^{83}$. Działacze stojący na jej czele (m.in. Bączkowski i Władysław Pelc) wkrótce mieli stać się kontynuatorami idei prometejskich w nowych okolicznościach. Koło wydawało kwartalnik „Wschód Orient” (1932-1938) oraz tygodnik „Biuletyn Polsko-Ukraiński” (1932-1938), na którego łamach publikowali młodsi zwolennicy Józefa Piłsudskiego.

Działalność wydawnicza Instytutu Wschodniego pozwoliła emigrantom na publikowanie prac z zakresu historii, polityki i wojskowości. Autorami korzystającymi z jego przychylności byli m.in.: Jan Kawtaradze, Dżafar Sejdamet, Ignacy Meszega, Mehmed Amin Rasulzade i Emir Bah Eddin Chursz ${ }^{84}$. Część z nich była jednocześnie wojskowymi, którym polska armia umożliwiła kontraktową służbę w Wojsku Polskim, co było jeszcze jednym z przejawów oddziaływania ideałów prometejskich ${ }^{85}$.

Instytut stał się w latach II RP niekwestionowanym centrum szeroko rozumianego prometeizmu, tj. aktywności nie stricte politycznej, ale również wymagającej pracy intelektualnej i eksperckiej. W Instytucie swoje wykłady prowadzili najwybitniejsi polscy naukowcy tego okresu: Marceli Handelsman, Ludwik Widerszal, Olgierd Górka, Włodzimierz Dzwonkowski, Adam Lewak, Witold Kamieniecki, Ludwik Kolankowski, Oskar Halecki, Stanisław Zajączkowski, Henryk Mościcki, Marian Zdziechowski, Józef Ujejski oraz dziennikarze i działacze społeczni: Wacław Łypacewicz, Marian Świechowski, Wojciech Stpiczyński ${ }^{86}$. Aktywność ta była dowodem nie tylko daleko-

\footnotetext{
81 A. Grzywacz, G. Mazur, Ruch prometejski..., s. 79.

82 I. P. Maj, W stużbie koncepcji prometejskiej - Instytut Wschodni w Warszawie, [w:] Ruch prometejski..., s. 207.

83 Tamże, s. 208-209.

84 A. Grzywacz, G. Mazur, Ruch prometejski..., s. 80.

85 Losy gruzińskich żołnierzy służących w Wojsku Polskim prezentuje film dokumentalny w reżyserii Jerzego Lubacha zatytułowany $W$ rogatywce i tygrysiej skórze z 2007 r.

86

M. Kornat, Ruch prometejski..., s. 81 .
} 
wzroczności i żywotności ruchu prometejskiego w kręgach intelektualnych, ale także realizmu politycznego, który wskazywał, że jakakolwiek przebudowa rzeczywistości geopolitycznej będzie niemożliwa bez nacisku na studia wschodnie i gruntowne wykształcenie polskiej elity politycznej w tym zakresie.

W wyniku pogarszającej się sytuacji gospodarczej na początku lat 30 . XX w. i chronicznego niedoinwestowania Instytutu jego dalsza działalność stanęła pod znakiem zapytania $^{87}$. Ostatecznie zakończył on działalność wraz z wybuchem II wojny światowej we wrześniu 1939 r. Wówczas grupa młodszych członków ruchu prometejskiego zdołała wypracować postulaty reformy ruchu, co stało się ważną okazją, by dostrzec zmianę pokoleniową i ideową głównych działaczy.

\section{EWOLUCJA I POTRZEBA REFORM}

Należy pamiętać, że ruch prometejski korzeniami ideowymi i politycznymi sięgał początków XX w. i rodził się w środowiskach lewicowych i socjalistycznych - głównie wśród aktywistów Polskiej Partii Socjalistycznej. Co niezwykle istotne, ruchy socjalistyczne, począwszy od co najmniej 1905 r., poczęły wysuwać hasła niepodległościowe, a istotę ich programów stanowily zasadniczo wątki narodowowyzwoleńcze ${ }^{88}$.

Czołowi prometeiści lat 20. należący do grona zwolenników lewicy to przede wszystkim: Hołówko, Wasilewski, Siedlecki, Adam Skwarczyński, Juliusz Łukasiewicz, Witold Jodko-Narkiewicz, Knoll, Janusz Jędrzejewicz, Jan Niecisław Baudouin de Courtenay, Stpiczyński, Aleksander Lednicki i Stanisław Paprocki ${ }^{89}$. Byli to na ogół działacze niepodległościowi wyrastający z konspiracyjnych tradycji Polskiej Organizacji Wojskowej. Dobrze orientowali się w sprawach rosyjskich, potrafili oceniać rozmiar zagrożenia działalnością agentury rosyjskiej, a później bolszewickiej, byli także nieufni wobec nacjonalistycznych terrorystów ukraińskich ${ }^{90}$. Naturalny był więc ich stosunek do ideologii bolszewickiej: jest to sita gruntownie rujnujaca to, co istnieje, zdolna do najwyższego rozpętywania żywiotów burzacych, mogaca zaptadniać masy nowymi ideami i popychać je natychmiast do czynów bezwzględnych ${ }^{91}$.

Podobne oblicze ideowe miały partie niepodległościowe wyrastające pośród narodów kaukaskich, na Ukrainie czy w rejonach krymsko-tatarskich. Ukraińska Partia Rewolucyjna działała pod przywództwem Symona Petlury i Andrija Liwyckiego. Socjalistyczne poglądy miał Noe Żordania, przyszły założyciel Gruzińskiej Partii Socjalistycznej, a także Ismail Bej Gasprinski i Dżafer Sejdamet - kierownicy partii Tatarów

\footnotetext{
I. P. Maj, W stużbie..., s. 215-218.
}

P. Libera, Ewolucja ruchu prometejskiego..., s. 222-223.

89 E. Charaszkiewicz, Referat o zagadnieniu prometejskim, [w:] Zbiór dokumentów pptk. Edmunda Charaszkiewicza, wstęp i przyp. A. Grzywacz, M. Kwiecień, G. Mazur, Kraków 2000, s. 56-80, Biblioteka Centrum Dokumentacji Czynu Niepodlegtościowego, t. 9. 
krymskich $^{92}$. Z czasem stało się jasne, że o ile początkowo to światopoglądowe powinowactwo było sprawą sprzyjającą prometeizmowi, to na późniejszym etapie mogło być istotną przeszkodą. Nurty wolnościowe w narodach prometejskich były podzielone, co znajdowało wyraz w odmiennych strategiach działania i stopniowalnym radykalizmie poszczególnych odłamów. W Gruzji obok socjaldemokratów funkcjonowali więc narodowi demokraci skupieni wokół Aleksandra Assatianiego. Niejednolity był również ruch górali kaukaskich, w którym występował znaczący odłam radykalnego, sprzeciwiającego się socjalistycznym rodakom ugrupowania pod przewodem Haidara Bammata. Polityk ten w 1935 r. przedstawił stronie polskiej memoriał, w którym zawarł wiele krytycznych uwag o gruzińskich socjaldemokratach i góralach północnokaukaskich wspierających Muhammada Saida Szamila. Bammat przestrzegał polskich prometeistów przed prorosyjskim i marksistowskim stanowiskiem socjaldemokratów, wytykając im przynależność do II Międzynarodówkii3. Zwracał uwagę na antytureckość konkurentów, ich niskie poparcie społeczne i ograniczone do wąskiego grona przedstawicielstwo polityczne.

Dwa lata później podobny dokument sporządził działacz Związku Państw Morza Czarnego, Ormianin Arszak Dżamalian. W skład tej organizacji wchodzili także aktywiści ukraińscy, gruzińscy i kozaccy. Dżamalian użył zbliżonych argumentów, akcentując jednak kwestię wykorzystania chwili, która - w jego opinii - zdawała się przybliżać moment upadku ZSRS i podjęcia aktywnej walki powstańczej. Stąd wzięły się postulaty poparcia środowisk zdecydowanych na budowanie powstańczych sekcji Związku, zawarcia przymierza z Ukrainą, uwzględnienia kwestii ormiańskiej oraz wsparcia wojskowego i finansowego ${ }^{94}$. Żaden z powyższych wniosków nie został spełniony przez polskie władze.

Mimo krytyki prometeiści zdołali zbudować szeroką sieć wpływów. Obejmowały one gruziński rząd emigracyjny kierowany przez Noego Ramiszwilego i Żordanię, Centrum Narodowe Azerbejdżanu pod przewodnictwem Amina Rasulzade, górali Kaukazu Północnego z Szamilem na czele, Tatarów krymskich skupionych wokół Dżafera Seydameta, ruch narodowy Kozaków kubańskich kierowany przez atamana Ignacego Biłyja, Finów wschodnich dowodzonych przez Ignacego Miszyga, Tatarów nadwołżańskich i Turkiestańczyków Mustafy Czokajewa, wreszcie Ukraińców wywodzących się spośród zwolenników atamana Petlury ${ }^{95}$.

Czynniki wymuszające reformę ruchu prometejskiego nie ograniczały się jednak tylko do kwestii wewnętrznych sporów. Bardzo istotną okoliczność stanowiły zmiany międzynarodowe, wpływające na plany polskiego kierownictwa odpowiedzialnego za dalszy rozwój prometeizmu. W 1932 r. Polska podpisała z ZSRS pakt o nieagresji, co przyczyniło się do większego zakonspirowania działań prometejskich. W tym samym czasie odnotowano zainteresowanie, jakie ruch wzbudzał wśród polityków niemiec-

\footnotetext{
92 P. Libera, Ewolucja ruchu prometejskiego..., s. 223.

93 Tamże, s. 231.

94 Tamże.

95 M. Kornat, Ruch prometejski..., s. 79-80; A. Grzywacz, G. Mazur, Ruch prometejski..., s. 81-82.
} 
kich, włoskich i japońskich. Z państw tych zaczęły wychodzić propozycje wsparcia politycznego i finansowego dla emigracji politycznej dotąd zgromadzonej w ośrodkach o polskich wplywach ${ }^{96}$.

Tego rodzaju presja musiała wzbudzać niepokój strony polskiej, dla której istotne było utrzymanie kluczowej roli Polski w wysiłku wyzwalania narodów przymusowo wcielonych do ZSRS. Obawy te spotęgował podpisany w 1936 r. niemiecko-japoński pakt antykominternowski ${ }^{97}$.

Równie istotna była zmiana pokoleniowa, którą spowodowała śmierć części polskich zwolenników idei prometejskich w pierwszej połowie lat 30. W 1931 r. Hołówko został zamordowany przez ukraińskich nacjonalistów, rok wcześniej zginął Stanisław Zaćwilichowski, w 1934 r. umarł Adam Skwarczyński, w 1935 r. Piłsudski, a rok po nim Wasilewski.

Do głosu doszli młodzi działacze wyrastający z kręgu m.in. Orientalistycznego Koła Młodych. Ton ich pracom nadawali głównie Bączkowski i Pelc, zdecydowani na zbliżenie ze środowiskami prawicy narodowej ${ }^{98}$. Swoją ofertę wobec tych środowisk opierali na wspólnym przekonaniu o polskim potencjale, zainteresowaniu nacjonalizmem, antykomunizmie i rosnącym znaczeniu militaryzmu. Znamienne w tym kontekście były słowa Bączkowskiego na temat misji prometejskiego czasopisma „Myśl Polska”; twierdził, że była to propaganda niezależnej mtodej myśli pitsudczyków, ujmowanej w kategoriach konstruktywnego nacjonalizmu?

\section{PUBLICYSTYKA KWARTALNIKA „WSCHÓD ORIENT”}

Dobrą egzemplifikacją kształtowania się myśli politycznej polskich zwolenników prometeizmu był wydawany w latach 30. kwartalnik „Wschód Orient”. Jego główni redaktorzy, z Bączkowskim na czele, ujmowali kwestie prometejskie na szerokim tle zagadnień kulturalnych, cywilizacyjnych i geopolitycznych. Pismo wydawane od 1932 r. przez Orientalistyczne Koło Młodych koncentrowało się wokół wydarzeń historycznych, kulturalnych, literackich i politycznych dotyczących państw i narodów sąsiadujących z Polską, narodów Kaukazu, a także Dalekiego Wschodu. Na łamach czasopisma publikowali emigracyjni przedstawiciele Gruzji, Azerbejdżanu, Armenii, Ukrainy, państw nadbałtyckich czy społeczności Tatarów krymskich. Przedmiot zainteresowania większości artykułów stanowiły: aktywność państwa sowieckiego, strategie rusyfikacyjne Moskwy, niebezpieczeństwo ujmowania kompleksu sowieckiego jako li tylko problemu $\mathrm{z}$ zakresu despotycznej państwowości wrogiego kraju ${ }^{100}$. To ostatnie, a więc ujmowanie relacji między państwami i narodami w kontekście walki bądź współpracy o szerszym,

\footnotetext{
96 P. Libera, Ewolucja ruchu prometejskiego..., s. 229.

97 Tenże, Polski prometeizm..., s. 91.

98 Tenże, Ewolucja ruchu prometejskiego..., s. 232.

99 W. Bączkowski, O wspólny front mtodych, „Myśl Polska” 1936, nr 13, s. 1.

100 Bilans sowiecki, „Wschód Orient” 1938, nr 3 (29), s. 31-36; N. Żordania, Polityka zagraniczna Rosji, „Wschód Orient” 1935, nr 1-2, s. 156-159.
} 
kulturotwórczym sensie, brało się z przekonania o kryzysie państw cywilizacji Zachodu w rywalizacji z azjatyckim Wschodem, a w praktyce z Rosją. Żordania w artykule zatytułowanym Problem światowy. Wschód przekonywał, że Europa pozbawia się kluczowych miejsc, tracąc wpływy i rezygnując z czynnej walki o Kaukaz i Turkiestan ${ }^{101}$. Tereny te stanowiły klucz do opanowania ludów Azji i odnowienia żywotności cywilizacji europejskiej. Japońska ekspansja oraz sowieckie działania przeciwstawiające się tej ostatniej nie znajdowały adekwatnej reakcji ze strony Anglii czy Francji. Wziąwszy pod uwagę doniosłość tej rywalizacji, należy zauważyć, że jej znaczenie dalece przekraczało obszar sporów terytorialnych, handlowych czy politycznych. Żordania, widząc w tym fragmencie globu aktualizację odwiecznego sporu Wschodu z Zachodem, zauważył jednocześnie tendencje państw europejskich do rezygnacji z udziału w walce i do ciasnej koncentracji na posiadanych koloniach, dyktowanej przez egoizm małych interesów. Gruzin ostrzegał przed pochopnym zarzuceniem spraw azjatyckich, oznaczającym początek końca cywilizacji atlantyckiej ${ }^{102}$. Tak zarysowany konflikt znajdował odzwierciedlenie także w publicystyce polskich autorów „Wschodu Orientu”. Naturalnym i jednocześnie najistotniejszym problemem stawało się pytanie o rolę i tożsamość Polski w starciu krańcowo odmiennych cywilizacji. To z kolei wymagało zasadniczej identyfikacji polskości, tego, co decyduje o polskiej specyfice, jej przywarach i przymiotach, wreszcie o sile bądź słabości polskiego ducha. W istocie dopiero odpowiedzi na te pytania mogły zapoczątkować wysuwanie postulatów prometejskich. Owe fundamenty tożsamości jednocześnie przesądzały o koniunkturalnym powodzeniu państwa z jednej strony i dalekosiężnym programie regionalnej mocarstwowości z drugiej. Mocarstwowości nie tylko niepozbawionej, ale wręcz integralnie zakładającej element misyjny.

Autorzy „Wschodu Orientu” zaczynali zatem od tej podstawowej konstatacji o korelatywizmie materii i ducha ${ }^{103}$. Aksjomatem zdawał się bowiem wpływ klimatu, terenu osiedlenia, krajobrazu na dyspozycje psychiczne jego mieszkańców. Specyfika geograficznego usytuowania Polski polegała na byciu pograniczem cywilizacji łacińskiej. W tereny polskiego Podola i wschodnich granic Wołynia wkraczał pas tzw. „mongolosfery", której emanacją były szerokie połacie stepu, półpustynie, burzany i piołuny rozciągające się od Wielkiego Muru Chińskiego, przez Tybet, Mongolię, Turkiestan, części Iranu, Afganistanu, Syberii Wschodniej, aż po wybrzeża mórz Kaspijskiego i Czarnego i wyżej wzmiankowane ziemie polskie ${ }^{104}$. Obecność Karaimów i Tatarów polskich była potwierdzeniem ponadczasowych wpływów kultury stepu, w tym wypadku odczuwanej szczególnie jaskrawo poprzez obecność potomków tych ludów. Jednak piętno odciśnięte przez kulturę tatarską jest znaczne głębsze; znajduje pełen wyraz w obyczajach, strojach, języku i sztuce wojskowej ${ }^{105}$. Orientalne wpływy, szcze-

\footnotetext{
101 Tenże, Problem światowy, „Wschód Orient” 1934, nr 1 (13), s. 1-5.

102 Tamże, s. 5.

103 W. Bączkowski, Wschód a Polska, „Wschód Orient” 1934, nr 2-3-4 (14-15-16), s. 17.

104 Tamże, s. 17-18.

105 Bączkowski przytaczał wiele interesujących przykładów wskazujących na orientalną proweniencję, np. ułani będący pierwotnie zamożniejszymi Tatarami litewskimi mieli nosić mongolską czapkę z kwadratowym wierzchołkiem, stanowiącą prototyp polskiej czapki - konfederatki. Tamże, s. 26.
} 
gólnie silne na polskich Kresach, były potęgowane przez obecność Ormian i Żydów, którzy podtrzymywali niejednolitość etniczno-kulturową i religijną, wzbogacając polskiego ducha i współkształtując jednocześnie dzieje nieskrystalizowanych narodowo Ukrainy i Białorusi. Należy podkreślić, że zjawisko cywilizacyjnego mieszania, rasowego wpływu obcego słowiańszczyźnie elementu wschodniego było oceniane co najmniej ambiwalentnie. Marzycielstwo, idealizm i awanturnictwo mieszały się z gnuśnością, słabą organizacją i obojętnością. Bączkowski, przywołując słowa Sienkiewicza, nie odmawiał im słuszności: Twardy i wytrwaty, z jasna myślq i silnq wola, otoczony wrogami, a niezmordowany $w$ walce $i$ uparty $w$ postanowieniu, zbudowat Polak $w$ wiekach średnich państwo swoje; ale nastąpita unia $z$ Litwa - i zmyst państwowy zacząt zanikać, rozcieńczyta się męskość od naptywu owych pierwiastków, które Wschodem nazywamy i w których tacza się i któca kontrasty górnolotnego marzenia i gnuśnej obojętności na zto, mistycznych wzlotów i grubego materializmu, niewolniczej bierności i anarchistycznej swawoli ${ }^{106}$.

Zakreślając granicę omawianych prądów, Bączkowski wskazuje na zachodnie krańce obecności żywiołów ruskich, tatarskich i ormiańskich. Pomimo, a raczej ze względu na aktywność tak licznych pierwiastków obcości Polska przedstawiała typ pewnej dziedziczności, stałości i uporządkowania. Emanacją tak rozumianej zachodniości były polityczna organizacja, sposób politycznego istnienia państwa Jagiellonów, a przede wszystkim polityczne źródła regeneracji kultury. Państwo polsko-litewskie grało rolę cywilizacyjnych szańców, na których ustawiały się narody ukraiński, białoruski, częściowo również nadbałtyckie. Podtrzymywanie odrębności narodowej i kulturowej miało być możliwe dzięki polskiemu przykładowi, który poprzez szerzenie zachodnich elementów ładu (urbanizacja miast, kościoły, zakony, wychowanie, prawo, władza ograniczająca anarchię) utrudniał duchowe unifikowanie wspomnianych narodów ${ }^{107}$. Jagiellońska polityczność, tworząc swego rodzaju „polonosfery”, duchowo regenerowała sąsiednie narody, a jednocześnie swoim dorobkiem przyciągała elity częściowo poddające się polonizacji. Nie oznaczało to wcale automatycznego porzucenia idei państwotwórczych. Wpisana w istotę „polonosfery” wolność, kierując losy Rzeczpospolitej Obojga Narodów nie w stronę monarszego absolutyzmu, ale szlacheckiej wolności, zbierała owoce właśnie w działaniach zagranicznych. W innym tekście Bączkowski podkreślał ową specyficzną dla polskiego sposobu bycia indywidualizację pragnień i działań wytwarzającą wolnościową formę wspólnoty i wspótistnienia zasadniczo przeciwnych ludzkiej masie podążającej za wolą wschodniego despoty ${ }^{108}$. Wolność rozumiano zatem nie tyle jako swobodę politycznej reprezentacji własnego interesu, ile jako rudyment narodowej kultury, nie jako element wtórny wobec polityczno-ustrojowego ładu, skutek stosunków władzy i poddania, osobistego przywileju, ale jako czynnik dziejo- i kulturotwórczy, stanowiący o dalszym przeżyciu i rozwoju narodów, zatem jako najwyższe i nieodzowne dobro wspólne.

\footnotetext{
106 Tamże, s. 30.

107 Tamże, s. 34.

108 Tenże, Dwutygodnikowi „Zet” w odpowiedzi, „Wschód Orient” 1935, nr 3 (19), s. 41.
} 
Te okoliczności, właściwie metahistoryczne, skłoniły redaktora „Wschodu Orientu” do następującej konstatacji: Mamy więc równe "prawo" być „hojnymi” i w przeciwnym kierunku i tereny tzw. Rosji Zachodniej, owe obszary Ukrainy, Biatorusi, Nowogrodczyzny, Pskowszczyzny - nazwiemy terenami polonosfery, tej emanacji państwowo-twórczych elementów, jakie tworzy międzymorze battycko-czarnomorskie, a jakie swój wyraz cielesny znalazto w postaci panstwowości litewsko-polskiej, jakie koncepcyjnie skrystalizowato się w pakcie hadziackim oraz wideach niepodlegtościowych ukrainskiej i biatoruskiej, a w przesztości - Nowogrodzkiej i Pskowskiej ${ }^{109}$.

Skupienie działań politycznych na wschodniej granicy wynikało także z przekonania o etnograficznym i historycznym charakterze granicy zachodniej ${ }^{110}$. Pozbawiona tych cech rubież wschodnia nie miała „odrębnego stylu” utrwalającego granicę traktatową. Jak pisał Bączkowski: Oto moce Polski Wschodniej, przelicytywujace sita wyrazu i atrakcji idee Polski Zachodniej, moce leżące u samych źródet naszej wielkości i naszego upadku'11.

Istotną rolę odgrywało napięcie między uniwersalizmem powszechnych kultur a pokusą myślenia polskocentrycznego. Bączkowski w swoich rozważaniach za niezbywalną zasadę uważał słowa prof. Feliksa Konecznego: [...] prawdą również być musi to, co uważam $w$ historii za prawo praw, a co stanowi u mnie dorobek i wynik pracy catego życia: nie można być cywilizowanym na dwa sposoby ${ }^{112}$. Konstatacje o wyjątkowości „polonosfery”, doświadczeniu wykraczającym dalece poza sferę spraw publicznych, nie powodowały jednak myśli o tworzeniu nowej cywilizacji. W polemice z Jerzym Braunem redaktor „Wschodu Orientu” przestrzegał przed popadaniem w błąd polegający na utracie poczucia przynależności cywilizacyjnej, na tworzeniu mitów i legend, za których sprawą zatracić można istotę własnej kulturowej tożsamości, albo na popadaniu w zachwyt nad dziedzictwem innych narodów ${ }^{113}$. Za przykład podawano Rosję, która od czasów cara Piotra I była przez wieki otwarta na żywioły niemiecki i francuski oraz fascynację kulturą antyczną, a także tworzące mity o germanizmie, nordyzmie i poganizmie Niemcy.

Szczególnie narażone na tego rodzaju uwikłanie w inność były pograniczne państwa słowiańskie: Bułgaria, Serbia, Ukraina czy Białoruś, o rachitycznych tradycjach państwowych i kulturowych. Idea tworzenia nowej cywilizacji, trzeciej drogi między Wschodem i Zachodem, opartej na słowianizmie, filozofii narodowej i mesjanizmie, była dla Bączkowskiego pomysłem niebywale niebezpiecznym, a u swego końca wręcz samobójczym. Odcięcie Polski od kulturowych źródeł Zachodu, wejście w etap tworzenia samoistnej cywilizacji otwierało ją na zagrożenie agresywnej, starszej i mocniejszej kultury rosyjsko-azjatyckiej ${ }^{114}$. Obecne w tej ostatniej pierwiastki słowiańskie miały

\footnotetext{
109 Tamże, s. 38.

110 Tenże, Uwagi na czasie, „Wschód Orient” 1935, nr 1-2 (17-18), s. 7.

111 Tenże, Wschód a Polska..., s. 39.

112 Tenże, Prometeizm polski a idea stowiańska, „Wschód Orient” 1935-1936, nr 4-1 (20-21), s. 4.

113 Tenże, O narodach marnotrawnych, o Polsce i prometeizmie (p. Jerzemu Braunowie w odpowiedzi), „Wschód Orient” 1936, nr 2-3 (22-23), s. 78-79.

114 Tamże, s. 81 .
} 
tylko ułatwiać penetrację początkującej, młodej, nieokrzepłej idei integralnego polski$z m u^{115}$. Myśl Brauna, choć wyraźnie fascynowała redaktora, była jednak pozbawiona świadomości rozmiarów i aktualności konfliktu, w którego środku Polska się wówczas znajdowała. Stąd brała się swoista filozofia wielkiego sporu: Nie bójmy sięnieuniknionego konfliktu, wyptywającego ze strukturalnej antynomii Europy - Rosji, lecz usitujmy tak zorganizować obozy walk, aby walczyli ze soba wrogowie, a nie pożarci o miedzę sąiedzi $[\ldots]^{116}$. Polsce przypisywał Bączkowski znaczenie przewodnika duchowego w już rozgrywającym się konflikcie, podmiotu, który musi tak pokierować walką, by ta doprowadziła do triumfu klasycznego ducha cywilizacji europejskiej. I choć wydarzenia II wojny światowej pokazały, że tego rodzaju ujęcie spraw było naiwne w świetle egoizmów narodowych i ustępliwości czołowych państw Zachodu wobec totalitaryzmów, dalekowzroczność tej wizji znalazła potwierdzenie w konflikcie zimnowojennym. Aktualności nie straciły również słowa redaktora o polskich formach ponadczasowości: Taka forma uniwersalizmu $w$ Polsce jest jej poczucie przynależności duchowej do Europy, jej charakter Przedmurza Zachodu oraz prometeizm jako wyraz misji wolnościowej i planu konstruktywnego w odniesieniu do Wschodu ${ }^{117}$.

Podobne stanowisko zajmował w swoim tekście Eugeniusz Wiśniowski, dla którego poczucie tymczasowości świata i wzrastanie świadomości narodowej społeczeństw były znakami bieżącego czasu. Opisując nacjonalizm polski, kształtujący się przede wszystkim w dobie zniewolenia kraju, Wiśniowski zwracał uwagę na jego czynny charakter. Aktywną, wytrwałą i uodparniającą walkę zbrojną uzupełniały działania spiskowe i konspiracyjne, podejmowane w przekonaniu o ideowej czystości programu niepodległościowego. I w tym wypadku nacjonalizm polski miał wykraczać poza wąskie ramy interesu jednej grupy etnicznej, wnosząc na sztandary hasła prometejskie. Wiśniowski dowodzil, że $w$ tym zjawisku uzewnętrznia się pierwiastek tolerancji i jak gdyby uniwersalizmu polskiego nacjonalizmu, który można nazwać solidaryzmem narodowościowym ${ }^{118}$. Losy Polski, polskiego nacjonalizmu, polskiego wysiłku niepodległościowego były nierozłączne z dążeniami wolnościowymi, z działaniem wymierzonym w opresyjnych agresorów, z kategorią śmiertelnego wroga. Historia polskie pojęcie polityczności zsyntetyzowała z kategorią wolności, wyzwolenia, akcji powstańczej i buntu. Było to zatem o tyle ciekawe ujęcie problemu, że z jednej strony uciekało od cierpiętniczej martyrologii, z drugiej zaś unikało powierzchownej krytyki powstańczej tradycji. Autorzy kwartalnika po prostu tę tradycję przyjmowali, rozumiejąc ją jako element ontologii polskości, tożsamość, której nie można i nie trzeba się wyzbywać, ale z której należy wyjąć to, co uniwersalne i potencjalnie mocarstwowe. Prometeiści znaleźli szerokie pole miedzy idealizmem wiary w czystą ideę polskości a chłodnymi, niekiedy oderwanymi od głębszej rzeczywistości postulatami realistów politycznych. Ową metapolityczną przestrzenią afirmacji były polskie dzieje widziane w perspekty-

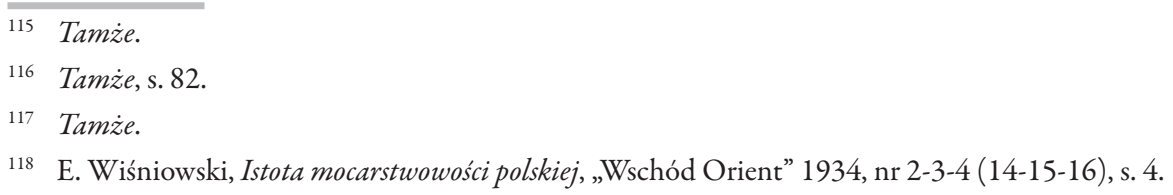


wie ciągłego wysiłku obrony klasyczności, odrębności, bogactwa treści, ich form realizacji i kultu wolności ${ }^{119}$.

Ten głęboko historycznie zakorzeniony pogląd skłaniał członków ruchu prometejskiego do posługiwania się częstokroć abstrakcyjnymi kategoriami. Refleksja na poziomie idei, aksjologii czy narodowej predestynacji nie brała się tylko i wyłącznie z natury opisywanego przedmiotu, jakim była polskość i jej duchowość. Za podstawowy wyróżnik sytuacji polskiej uważano radykalną alternatywę wyrażoną przez Jana Kucharzewskiego słowami: jest to wzniosty i tragiczny los Polski: być wielka lub utracić wolnośćl ${ }^{120}$. Przeszłość Rzeczpospolitej, pojmowana głębiej niż jako zbiór kwantytatywnych faktów i zdarzeń, stanowiła intelektualne wyzwanie zrozumienia i podjęcia jej dalszych losów. To z kolei, zdaniem prometeistów, zawierać się miało w maksymalizmie prezentowanych programów. Uważano, że skoro przed losami narodu rysowała się skrajnie radykalna egzystencjalnie ontologia, owo „być albo nie być” przyszłej Polski, należało podjąć się pracy maksymalnej, oznaczającej wykroczenie poza sens działań ledwie politycznych. Formowanie narodu wokół wspomnianych idei, dyktowane szczególnie przez historię zaborów, miało uprawniać do szczególnie pojętego przeznaczenia: 100 lat niewoli daty Polsce potężne narzędzie maksymalizmu mesjanistycznego wraz z jego największym owocem - prometeizmem polskim ${ }^{121}$. Owo ulokowanie spraw polskich w rzędzie najwyższych idei nie było prostą konsekwencją nacjonalizmu, z którym prometeiści, szczególnie młodszego pokolenia, sympatyzowali, czy raczej który uznawali za czynnik determinujący obecną rzeczywistośćc ${ }^{122}$. Istotne znaczenie miał również sprzeciw autorów wobec optymistycznych usypiaczy czujności $i^{123}$. Przekleństwo to, wskazujące na uśpienie polityczności, zawieszenie jej w imię tymczasowego spokoju, petryfikowanie stanu obecnego, było największym zagrożeniem i rozsadnikiem spoistości wspólnoty. Maksymalizm miał też wyrastać z szerszych pobudek poszukiwania podmiotowości już nie tyle politycznej, co historycznej czy historiozoficznej. Olgierd Górka, wyrażając swój sprzeciw wobec rzekomo niezmiennych i nieodwracalnych „praw historii”, wskazywał na rolę ludzi i jednostek. To od inteligencji umysłu przywódców miało zależeć powodzenie realizacji maksymalistycznych koncepcji tworzonych niejako wbrew warunkom czysto fizycznym, przeciw rzekomemu determinizmowi nieubłaganej historii ${ }^{124}$.

Mocne przekonanie o nieodwracalnym sprzężeniu elementów ideowych, filozoficznych i cywilizacyjnych ze współczesnością wypełnioną sprzecznościami wyrażonymi wojną kultur kazało reprezentantom prometeizmu dopatrywać się we własnej wizji recepty na problemy ideowe i geopolityczne. Refleksja nie ograniczała się tylko do pozio-

119 W. Bączkowski, Od Hannibala do Pitsudskiego, „Wschód Orient” 1939, nr 1 (31), s. 2-5.

120 Tenże, Prometeizm polski..., s. 1.

121 Tamże, s. 5.

122 M. E. Resul-Zade, Synteza epoki, „Wschód Orient” 1938, nr 2 (28), s. 10-11; Bilans sowiecki..., s. 32.

123 W. Bączkowski, Prometeizm polski..., s. 1.

124 O. Górka, Rola ludzi a warunków w tworzeniu Europy Wschodniej XX wieku, „Wschód Orient” 1936, nr 2-3 (22-23). 
mu idei i historii, ale niezmiennie wpisywała się w wymóg uwzględnienia chwili bieżącej. Oznaczało to branie pod uwagę wymiernych, skonkretyzowanych danych, takich jak rodzaj, długość, ukształtowanie granic czy liczba, rodzaj, charakter i kierunki naporu państw sąsiadujących z Polską ${ }^{125}$. Nie ulegało wątpliwości, że to przede wszystkim granica wschodnia przedstawia największe zagrożenie (choć oczywiście nie lekceważono zagrożenia niemieckiego i logiki Rapallo), upostaciowione przez moskiewskie zabiegi komunizowania i rusyfikowania jednocześnie, ale także dane empiryczne. Z łącznej długości $5531 \mathrm{~km}$ granicy polskiej aż ok. $5000 \mathrm{~km}$ było mniej lub bardziej potencjalnie zagrożonych. Co więcej, brak naturalnych granic przyrodniczych poza południowymi obszarami państwa jeszcze bardziej wystawiał Polskę na atak nieprzyjaciela. Wskazywano także na czynniki liczby ludności i gęstości zaludnienia. W Rzeczpospolitej na jeden km granicy przypadało raptem 6 tys. osób, w Rosji natomiast aż 33 tys. Tzw. „współczynnik naporu politycznego", obliczany jako iloraz stosunku ilości ludności państw sąsiednich do własnej liczby mieszkańców, dla Polski wynosił 7,6, podczas gdy np. dla Niemiec tylko $1,9^{126}$. To także z tego rodzaju spostrzeżeń wynikały kwalifikacje wrogów i przyjaciół państwa polskiego, których kryterium opierało się zarówno na dziejowej łączności kultur, jak i na obserwacjach bieżącej sytuacji: Negując ludzkość, nie dlatego, iż jest lub nie jest fikcja, szukamy przyjaciót i sit przyjaznych poza narodem polskim. To poczucie miary każe nam tę ludzkość rozparcelować na wrogów i przyjaciót $t^{127}$. Publicyści kwartalnika zauważali wiele okoliczności powodujących wzrost szans powodzenia idei prometejskiej właśnie ówcześnie ${ }^{128}$. Do pomyślnych warunków zaliczano konflikt chińsko-(sowiecko)-japoński, skutkujący niestabilną sytuacją na wschodnim przedpolu Rosji sowieckiej, rosnącymi wpływami Japonii i co za tym idzie pogarszaniem stosunków sowiecko-japońskich ${ }^{129}$. Nie dało się również nie dostrzec narastających sprzeczności między centralizmem, deklarowanym internacjonalizmem i rewolucjonizmem Moskwy a dążeniami autonomicznymi poszczególnych republik sowieckich, w których poczucie narodowej odrębności skłaniało do kontestacji polityki rosyjskich komunistów wysyłanych do dyscyplinowania lokalnych partii komunistycznych ${ }^{130}$. Skrupulatnie odnotowywano pogarszanie się relacji niemiecko-sowieckich w latach $30 .{ }^{131} \mathrm{Z}$ punktu widzenia antysowieckich planów prometejskich pakt antykominternowski także stwarzał sprzyjającą w polityce międzynarodowej koniunkturę antykomunistyczną. Co więcej, zauważano nieusuwalny antagonizm $w$ relacjach turecko-rosyjskich, pogarszanych przez czwórporozumienie państw muzułmańskich (Afganistanu, Iranu, Turcji i Iraku), oraz rosyjskie

125 T. Radwański, Idea prometejska na tle geopolityki Polski, „Wschód Orient” 1935-1936, nr 4-1 (20-21), s. 18.

Tamże, s. 18-19.

127 W. Bączkowski, O narodach marnotrawnych..., s. 83.

128 Tenże, Problem prometejski, „Wschód Orient” 1938, nr 1 (27), s. 4-5.

129 W. Pelc, Zarys stosunków rosyjsko-japońskich, „Wschód Orient” 1935, nr 1-2 (17-18), s. 86.

130 J. Naumenko, Ukraina Sowiecka, "Wschód Orient” 1935, nr 3 (19), s. 2-8; M. Resul-Zade, Rzady narodowe w Azerbejdżanie..., „Wschód Orient” 1935, nr 1-2 (17-18), s. 22-33.

131 W. Bączkowski, Uwagi o rosyjskiej polityce Niemiec, „Wschód Orient” 1938, nr 3 (29), s. 4. 
zaangażowanie w hiszpańską wojnę domową. To ostatnie wiązało się z wciąganiem sowieckiego państwa w rywalizację w basenie Morza Śródziemnego ${ }^{132}$.

Barierą we wprowadzaniu w życie idei prometejskich były amerykańskie interesy w Chinach oraz brytyjskie na Dalekim Wschodzie, blokujące japońską ekspansję dokonującą się kosztem ZSRS. Istotnym problemem był brak spójnego planu działania wobec Sowietów. Niemcy zdawały się koncentrować w pierwszej kolejności na komunistyczno-żydowskich aspektach funkcjonowania ZSRS, co czyniło z ich stanowiska raczej formę powierzchownej i tymczasowej akcji ideologicznej. Obawiano się działań Berlina skierowanych na przyszłą, ewentualną „białą” Rosję. Podobną ignorancję w sprawach prometejskich wykazywali Japończycy - przeważnie niezainteresowani treścią prometejskich organów i przez to podatni na sowiecką propagandę niepodzielnej ZSRS. Ruch prometejski nie przyciągał również uwagi w państwach muzułmańskich, niekiedy tylko był traktowany jako instrument terytorialnej ekspansji tureckiej czy irańskiej ${ }^{133}$. Samotność koncepcji prometejskiej potęgowała obojętność państw bałkańskich, Szwecji oraz Rumunii. Zatem wizja prometejska nie znajdowała większego zainteresowania w innych krajach. Redaktor Bączkowski mimo to nie tracił nadziei: Atoli zestawienie tych minusów z plusami chwili obecnej, przy należytym zaakcentowaniu powszechnego dziś w świecie upadku roli pansstw zwycięskich w wojnie światowej oraz wzmożenia tendencji rewizjonistycznych w świecie, nakazuje zaakcentować zdecydowana przewage czynników dodatnich nad ujemnymi ${ }^{134}$.

Konflikt światowy, tendencje do dekompozycji dawnych mocarstw, dekolonizacja, zimnowojenna polaryzacja, wreszcie wyzwolenie państw narodowych z sowieckiej niewoli pod koniec XX w. - to wszystko mieściło się w prometejskiej doktrynie politycznej. Widoczna jest przewaga elementów uniwersalnych, metapolitycznych i maksymalistycznych w koncepcjach prometejskich artykułowanych szczególnie przez młodszą generację działaczy. Twierdzenia, że ruch prometejski był opcją defensywną ${ }^{135}$, są niepozbawione racji, pomijają jednak sedno prometejskiego podejścia do racji stanu.

I wtaśnie jako wyraz naszego postannictwa, sharmonizowanego [tak w oryginale przyp. B.Ś.] z racją stanu państwa, prometeizm polski winien byćprzyjęty jako jedna z czo-

132 Tenże, Problem prometejski..., s. 4.

133 Tamże, s. 5.

134 Tamże.

135 W ocenie Marka Kornata idea prometejska miata istotne znaczenie dla polskiej polityki wschodniej, ale byta tylko wizja na okoliczność wewnętrznego rozktadu ZSRS jako wielonarodowego imperium, albo też na wypadek wielkiego przewrotu w geopolityce Europy, który musiatby dojść do skutku tylko na drodze wielkiej wojny. Wojny takiej Polska planować nie mogta. Byta to więc idea mimo wszystko defensywna - warto podkreślić to jeszcze raz - gdyż stanowita polska odpowiedź na imperializm ideowy państwa Sowietów, które postugiwato się instrumentem Kominternu i narzędziem ideologii komunistycznej. M. Kornat, Idea prometejska..., s. 89. Jednak wbrew tym słowom duża część młodszych członków ruchu prometejskiego genezy swojego programu upatrywała nie tyle w prostej reakcji na poczynania sowieckie, ani tym bardziej w ideologicznej rywalizacji, ale w znacznie silniej zakorzenionych doświadczeniach cywilizacyjnych. Refleksja dokonywana na tym poziomie, wraz ze świadomością doniosłości konfliktu Wschód-Zachód, powodowała wysuwanie aktywnego i maksymalistycznego programu prometejskiego, ujmującego zagrożenie ze strony Rosji sowieckiej w kategoriach kulturowych. 
towych dróg ku wielkości i potędze, wskazujacy nam cel wspólny i jednoczacy, jako dogmat Polaka wspótczesnego - pisał Bączkowski ${ }^{136}$. Ta mesjańsko-narodowo-mocarstwowo-republikańska definicja najlepiej oddaje ducha tej wizji.

\section{PODSUMOWANIE}

W okresie przeobrażeń geopolitycznych, wewnętrznych przetasowań politycznych i generacyjnej zmiany środowisk emigracyjnych zaczęto domagać się reformy ruchu prometejskiego. Chciano pozyskać przede wszystkim młodszych działaczy emigracyjnych, którzy, w przeciwieństwie do starszej generacji, wykazywali większą aktywność i radykalniejszą postawę. To z kolei miało służyć wysuwaniu żądań niepodległościowych wprost, jawnie i zdecydowanie ${ }^{137}$. Choć ostatecznie próby nadania ruchowi większej dynamiki i zbudowania znacznych wpływów w narodach zniewolonych nie powiodły się, warto zwrócić uwagę kilka istotnych kwestii.

Ruch promieniował na coraz szersze środowiska intelektualne; w kręgu jego oddziaływania znaleźli się publicyści „Buntu Młodych” i późniejszej „Polityki” redagowanej przez Jerzego Giedroycia ${ }^{138}$. Uwidocznił się wówczas imperatyw myślenia w kategoriach jagiellońskich. Ta regionalna, wolnościowa mocarstwowość została nazwana przez Adolfa Bocheńskiego zdrowym imperializmem. Pisał on: przez zdrowy imperializm XX wieku rozumiemy dążenie do związu kilku państw celem wspólnej obrony, bez panowania jednego państwa czy narodu nad drugim i bez zbyt wielkiego ich wtracania się wzajemnego $w$ sprawy wewnętrzne kontrahenta ${ }^{139}$. Choć działaczy z kręgu Giedroycia i Bocheńskiego nie sposób wprost nazwać prometeistami, w sposób ewidentny ich stanowisko łączy z prometeizmem przekonanie co do źródła politycznej siły Rzeczpospolitej. Fundamentalne znaczenie nadawano przekonaniu, że podmiotowość i status Polski są funkcją jej wartości na Wschodzie. Innymi słowy, od faktycznej siły Polski w tej części Europy zależy jej polityczne i międzynarodowe znaczenie.

Krytycy ruchu prometejskiego, do których zaliczali się przede wszystkim politycy endeccy, zwracali uwagę na szereg niebezpieczeństw związanych z powrotem do hasła

136 W. Bączkowski, Prometeizm polski..., s. 5.

137 P. Libera, Ewolucja ruchu prometejskiego..., s. 238-239.

138 W. Karpiński, Polski Prometeusz..., s. 7-10. W okresie powojennym przebywający na emigracji Giedroyc był współautorem tzw. doktryny ULB. Wraz z innym publicystą „Kultury”, Juliuszem Mieroszewskim, sformułował koncepcję polityki wschodniej opartej na współpracy i wspieraniu niepodległościowych aspiracji narodów Ukrainy, Litwy i Białorusi. W pierwszej fazie tworzenia programu autorzy dokonali krytycznej oceny idei federalistycznych, uznając je za anachroniczne i nieprzystające do nowych uwarunkowań okresu pojattańskiego. Punktem wyjścia ich rozumowanie były rezygnacja z terytorialnych roszczeń wobec dawnych Kresów Rzeczpospolitej, budowanie silnych więzi ze wschodnimi sąsiadami i tym samym przeciwstawienie się wpływom Rosji. Por. M. Kornat, Realizm środków, idealizm wizji. O geopolitycznej wizji Jerzego Giedroycia i Juliusza Mieroszewskiego, [w:] Przeklęte miejsce Europy? Dylematy polskiej geopolityki, red. J. Kloczkowski, Kraków 2009, s. 225-243, Polskie Tradycje Intelektualne, 8.

139 A. Bocheński, Między Niemcami a Rosją, wstęp K. M. Ujazdowski, Kraków-Warszawa 2009, s. 90, Biblioteka Myśli Politycznej, 69. 
„za wolność naszą i waszą”. Przede wszystkim program ten nawiązywał do idei Polski przedrozbiorowej, a wiązał kształt granic Rzeczpospolitej z czasami odległymi. W opinii części młodych narodowców, m.in. Jędrzeja Giertycha i Zygmunta Wojciechowskiego, było to jego słabością. Anachroniczności programu miała towarzyszyć tendencja do kwestionowania ładu wersalskiego. W tej wizji geopolitycznej kluczowym kierunkiem polityki zagranicznej Polski nie był Wschód, gdzie raczej należało spodziewać się niezmienności rosyjskiej dominacji, ale tradycyjnie polskie etnicznie ziemie na północnym zachodzie. Stąd przekonanie, że grą naprawdę wartą wysiłku jest polsko-niemiecka rywalizacja o ujście Wisty ${ }^{140}$.

W rezultacie wybuchu II wojny światowej idea prometejska poniosła porażkę - nie udało się rozczłonkować imperium sowieckiego, które 17 września 1939 r. dokonało agresji na Rzeczpospolitą. To jednak nie sprawia, że bilans dokonań prometejskich w II RP należy uznać za ujemny. Udało się zbudować gęstą sieć kontaktów politycznych, wojskowych i środowiskowych, ostatecznie powiodła się akcja zjednoczenia państw kaukaskich we wspólnej Konfederacji Kaukaskiej, do której z czasem przyłączyli się nawet nieprzejednani Ormianie ${ }^{141}$. Wiele środowisk emigracyjnych zabiegało o polskie wsparcie, widząc w nim szansę na realizację własnych postulatów. Kwestia naruszania przez prometeizm ładu wersalskiego, co mogło zagrozić integralności terytorialnej Rzeczpospolitej, została natomiast przekreślona przez międzynarodowe wydarzenia polityczne lat $30 . \mathrm{XX} \mathrm{w}^{142}$

Przede wszystkim jednak prometeizm po latach doczekał się potwierdzenia swojej podstawowej tezy, że utrzymanie ZSRS w dotychczasowym, wielonarodowym ksztalcie nie było możliwe. Co więcej, myśl prometejska, choć przegrana w starciu z polityką III Rzeszy i Rosji sowieckiej, pozostała konstrukcją kompletną, przemyślaną i realistyczną, zawierającą zarówno elementy defensywne, jak i zdecydowanie ofensywne. Także w polityce zagranicznej III RP można znaleźć wątki nawiązujące do tradycji prometejskich. Szczególne znaczenie przypisywano wschodnim sąsiadom, zauważono zależność między polskim bezpieczeństwem a niepodległością i suwerennością państw bałtyckich i Ukrainy. Polski wkład w pomarańczową rewolucję i zaangażowanie polityczne w trakcie konfliktu rosyjsko-gruzińskiego w 2008 r. to dowody na ciągłą ważność wschodniego wektora polskiej polityki zewnętrznej.

Sposobność do rozwoju neoprometejskich koncepcji stworzyła akcesja państw regionu Europy Środkowo-Wschodniej do Unii Europejskiej. Rzeczpospolita zyskała narzędzia umożliwiające przyciąganie państw Europy Wschodniej do instytucji zachodnich. Aktualność prometejskiego przesłania dostosowanego do zmienionych okoliczności pokazał prezydent Lech Kaczyński. Tworząc projekty częściowego geopolityczno-

140 Z. Wojciechowski, Między Niemcami a Rosją. Z powodu ksiązek: Adolfa Bocheńskiego Między Niemcami a Rosją $i$ W. Bączkowskiego Grunwald czy Pilawce?, Poznań 1938, s. 21-23.

141 Antagonizm narodowy i religijny oraz pamięć o tureckich zbrodniach dokonanych na ormiańskim narodzie powodowały nieco odmienną orientację geopolityczną - na pierwszym planie znajdowały się antytureckie hasła, zaś polityka wobec Rosji była wtórna wobec konfliktu z Turcją. Z kolei dla Gruzji i Azerbejdżanu wrogiem zasadniczym była Rosja. T. Schaetzel, Racja stanu..., s. 109-112.

142 M. Kornat, Idea prometejska..., s. 79. 
-energetycznego uniezależnienia od Rosji, chciał wzmocnić niezawisłość regionu oraz umożliwić Ukrainie i państwom Kaukazu integrację z zachodnimi strukturami bezpieczeństwa i współpracy gospodarczej. Było w tym miejsce zarówno na realizm środków energetycznych i ambicję wizji przebudowy sieci zależności w regionie, jak i na przekonanie o wspólnocie doświadczenia i interesów tej części Europy. Energetyczne szczyty w Krakowie czy Kijowie, skupiające najwyższe władze państw regionu, miały potencjał prometejskiej współpracy, natomiast interwencja szefów rządów i prezydentów Litwy, Łotwy, Estonii, Ukrainy i Polski w czasie wojny rosyjsko-gruzińskiej jest namacalnym dowodem polskiego potencjału w budowaniu koalicji państw na Wschodzie. Prometeizm wciąż może być użytecznym drogowskazem, jak ów wschodnioeuropejski potencjał aktualizować.

Dlatego też uzasadnione jest rozpatrywanie prometeizmu w kontekście polskiej racji stanu. Tę ostatnią definiuje się jako wzglad na dobro państwa, zasada postępowania politycznego, kryterium oceny dziatań politycznych, priorytet dla interesu państwowego, przewaga interesu zbiorowego, prymat nad normami moralnymi i prawnymi oraz jako argument na rzecz określonego dziatania w życiu spotecznym ${ }^{143}$.

Istotne jest rozróżnienie na węższe i szersze znaczenie racji stanu. W pierwszym oznacza ona uzasadnienie jednorazowego, wąskiego i tymczasowego działania politycznego, wywołanego stanem nadzwyczajnym, warunkami, które zmuszają do podjęcia niezbędnych działań. Szersze rozumienie omawianego pojęcia odnosi się do dłuższej perspektywy funkcjonowania państwa, w której przede wszystkim zabezpieczane jest jego przetrwanie, a także realizowane są jego żywotne interesy. Wątki tak rozumianej racji stanu są łatwo dostrzegalne w publicystyce autorów kwartalnika „Wschód Orient” i, szerzej, w myśli politycznej prometeistów. Choć byli oni krytykowani za utopijność i oparcie całej koncepcji na nierealistycznych ideałach, należy zauważyć, że prometeizm łączył uniwersalne wartości z zabiegami o sprawnie działające instytucje. Ruch operował realistycznymi środkami (finanse, armia, wywiad, szkolenia wojskowe), które bazowały na wyrazistych fundamentach ideowych. Realizm prometejskiej racji stanu oznaczał umieszczenie programu polityki zagranicznej w całościowej wizji przebudowy porząaku politycznego i stosunków narodowościowych w regionie.

\section{BIBLIOGRAFIA}

\section{Publikacje drukowane:}

Literatura źródłowa:

- dokumenty:

Traktat pokoju między Polska a Rosja i Ukraina, podpisany w Rydze dnia 18 marca 1921 r., Dz. U. 1921, nr 49, poz. 300.

143 A. Rzegocki, Racja stanu a polska tradycja myślenia o polityce, Kraków 2008, s. 48, Biblioteka Myśli Politycznej, 60 . 
- monografie i opracowania:

Bocheński A., Między Niemcami a Rosją, wstęp K. M. Ujazdowski, Kraków-Warszawa 2009, Biblioteka Myśli Politycznej, 69.

Cat-Mackiewicz S., Historia Polski od 11 listopada 1918 do 17 września 1939, Kraków 2012, Pisma wybrane.

Dmowski R., Polityka polska i odbudowanie państwa, Warszawa 1925.

Krasiński Z., Pisma filozoficzne i polityczne, Kraków-Warszawa 1912, Pisma, t. 7.

Tadeusz Hotówko o demokracji, polityce i moralności życia publicznego, wstęp, wybór i oprac. A. Chojnowski, Warszawa 1999.

Wojciechowski Z., Między Niemcami a Rosją. Z powodu książek: Adolfa Bocheńskiego Między Niemcami a Rosją $i$ W. Bączkowskiego Grunwald czy Pilawce?, Poznań 1938.

- rozdziały w pracach zbiorowych:

Bączkowski W., Uwagi o istocie sity rosyjskiej, [w:] tenże, O wschodnich problemach Polski. Wybór pism, wybór i wstęp J. Kloczkowski, P. Kowal, Kraków 2000, Biblioteka Myśli Politycznej, 32.

Bączkowski W., Uwagi o Kaukazie, [w:] tenże, O wschodnich problemach Polski. Wybórpism, wybór i wstęp J. Kloczkowski, P. Kowal, Kraków 2000, Biblioteka Myśli Politycznej, 32.

Charaszkiewicz E., Referat o zagadnieniu prometejskim, [w:] Zbiór dokumentów pptk. Edmunda Charaszkiewicza, wstęp i przyp. A. Grzywacz, M. Kwiecień, G. Mazur, Kraków 2000, Biblioteka Centrum Dokumentacji Czynu Niepodlegtościowego, t. 9.

Wasilewski L., Bolszewizm, „Kultura Polski” 1918, nr 7, [w:] tenże, Drogi porozumienia. Wybór pism, wybór, wstęp i przyp. B. Stoczewska, Kraków 2001, Biblioteka Klasyki Polskiej Myśli Politycznej, t. 6.

Wasilewski L., Polityka narodowościowa Sowietów, „Przegląd Polityczny” 1925, nr 5-6, [w:] tenże, Drogi porozumienia. Wybór pism, wybór, wstęp i przyp. B. Stoczewska, Kraków 2001, Biblioteka Klasyki Polskiej Myśli Politycznej, t. 6.

Wasilewski L., Sprawa kresów wschodnich, „Droga” 1924, nr 5, [w:] tenże, Drogi porozumienia. Wybór pism, wybór, wstęp i przyp. B. Stoczewska, Kraków 2001, Biblioteka Klasyki Polskiej Myśli Politycznej, t. 6.

Wasilewski L., Wnioski koniunkturalne, „Biuletyn Polsko-Ukraiński” 1933, nr 24, [w:] tenże, Drogi porozumienia. Wybór pism, wybór, wstęp i przyp. B. Stoczewska, Kraków 2001, Biblioteka Klasyki Polskiej Myśli Politycznej, t. 6.

- artykuły w czasopismach naukowych:

Protokót pierwszego posiedzenia Komitetu Obrony Państwa z dnia 23 listopada 1926 r., oprac. P. Stawecki, „Kwartalnik Historyczny” 1988, nr 3.

- artykuły prasowe:

Bączkowski W., Dwutygodnikowi „Zet” w odpowiedzi, „Wschód Orient” 1935, nr 3 (19).

Bączkowski W., O wspólny front mtodych, „Myśl Polska” 1936, nr 13.

Bączkowski W., O narodach marnotrawnych, o Polsce i prometeizmie (p. Jerzemu Braunowie wodpowiedzi), „Wschód Orient” 1936, nr 2-3 (22-23). 
Bączkowski W., Od Hannibala do Pitsudskiego, „Wschód Orient” 1939, nr 1 (31).

Bączkowski W., Problem prometejski, „Wschód Orient” 1938, nr 1 (27).

Bączkowski W., Prometeizm polski a idea stowiańska, „Wschód Orient” 1935-1936, nr 4-1 (20-21).

Bączkowski W., Uwagi na czasie, „Wschód Orient” 1935, nr 1-2 (17-18).

Bączkowski W., Uwagi o rosyjskiej polityce Niemiec, „Wschód Orient” 1938, nr 3 (29).

Bączkowski W., Wschód a Polska, „Wschód Orient” 1934, nr 2-3-4 (14-15-16).

Bilans sowiecki, „Wschód Orient” 1938, nr 3 (29).

Górka O., Rola ludzi a warunków w tworzeniu Europy Wschodniej XX wieku, „Wschód Orient” 1936, nr 2-3 (22-23).

Naumenko J., Ukraina Sowiecka, „Wschód Orient” 1935, nr 3 (19).

Pelc W., Zarys stosunków rosyjsko-japońskich, „Wschód Orient” 1935, nr 1-2 (17-18).

Radwański T., Idea prometejska na tle geopolityki Polski, „Wschód Orient” 1935-1936, nr 4-1 (20-21).

Resul-Zade M. E., Rządy narodowe w Azerbejdżanie..., „Wschód Orient” 1935, nr 1-2 (17-18).

Resul-Zade M. E., Synteza epoki, „Wschód Orient” 1938, nr 2 (28).

Wiśniowski E., Istota mocarstwowości polskiej, „Wschód Orient” 1934, nr 2-3-4 (14-15-16).

Żordania N., Polityka zagraniczna Rosji, „Wschód Orient” 1935, nr 1-2 (17-18).

Żordania N., Problem światowy, „Wschód Orient” 1934, nr 1 (13).

Literatura pomocnicza:

- monografie i opracowania:

Besançon A., Święta Ruś, przeł. Ł. Maślanka, Warszawa 2012, Biblioteka Teologii Politycznej, t. 6.

Bruski J. J., Między prometeizmem a Realpolitik. II Rzeczpospolita wobec Ukrainy sowieckiej 1921 -1926, Kraków 2010, Studia z Historii XX Wieku, t. 10.

Huntington S. P., Zderzenie cywilizacji $i$ nowy ksztatt tadu światowego, przeł. H. Jankowska, Warszawa 2004, Spectrum.

Kopaliński W., Stownik mitów i tradycji kultury, Warszawa 1985.

Mochnacki M., Powstanie narodu polskiego w roku 1830 i 1831, oprac. i przedm. S. Kieniewicz, t. 1-2, Warszawa 1984.

Nowak A., Historie politycznych tradycji. Pitsudski, Putin i inni, Kraków 2007, Arkana Historii.

Pipes R., Rosja bolszewików, przeł. W. Jeżewski, Warszawa 2005.

Pruszyński K., Trzynaście opowieści, Warszawa 1995.

Rzegocki A., Racja stanu a polska tradycja myślenia o polityce, Kraków 2008, Biblioteka Myśli Politycznej, 60.

Werschler I., Tadeusz Hotówko. Życie i dziatalność. Z dziejów obozu belwederskiego, Warszawa 1984.

- rozdziały w pracach zbiorowych:

Bartoszewicz H., Prometeizm Romana Knolla, [w:] Ruch prometejski i walka o przebudowe Europy Wschodniej (1918-1940). Studia i szkice, red. M. Kornat, Warszawa 2012. 
Bruski J. J., W trójkącie Warszawa-Paryż-Praga. Reaktywacja wspótpracy polsko-ukrainskiej 1925-1926, [w:] Ruch prometejski i walka o przebudowe Europy Wschodniej (1918-1940). Studia i szkice, red. M. Kornat, Warszawa 2012.

Kornat M., Idea prometejska a polska polityka zagraniczna (1921-1939/1940), [w:] Ruch prometejski i walka o przebudowe Europy Wschodniej (1918-1940). Studia i szkice, red. M. Kornat, Warszawa 2012.

Kornat M., Realizm środków, idealizm wizji. O geopolitycznej wizji Jerzego Giedroycia i Juliusza Mieroszewskiego, [w:] Przeklęte miejsce Europy? Dylematy polskiej geopolityki, red. J. Kloczkowski, Kraków 2009, Polskie Tradycje Intelektualne, 8.

Kruszyński M., Wydziat Wschodni Ministerstwa Spraw Zagranicznych a idea rozbicia Rosji Radzieckiej w latach dwudziestych XX wieku, [w:] Ruch prometejski i walka o przebudowe Europy Wschodniej (1918-1940). Studia i szkice, red. M. Kornat, Warszawa 2012.

Libera P., Ewolucja ruchu prometejskiego w okresie międzywojennym, [w:] Ruch prometejski i walka o przebudowe Europy Wschodniej (1918-1940). Studia i szkice, red. M. Kornat, Warszawa 2012.

Łossowski P., Ksztattowanie sie państwa polskiego i walka o granice (listopad 1918 - czerwiec 1921), [w:] Historia dyplomacji polskiej (potowa X-XX w.), t. 4: 1918-1939, red. tenże, Warszawa 1995.

Maj I. P., W stużbie koncepcji prometejskiej - Instytut Wschodni w Warszawie, [w:] Ruch prometejski i walka o przebudowę Europy Wschodniej (1918-1940). Studia i szkice, red. M. Kornat, Warszawa 2012.

Materski W., Kaukaz w polityce międzynarodowej 1917-1921, [w:] Ruch prometejski i walka o przebudowe Europy Wschodniej (1918-1940). Studia i szkice, red. M. Kornat, Warszawa 2012.

Nowak A., Przez Ukraine i Kaukaz na Petersburg: poczatek drogi do koncepcji prometejskich w polskiej myśli politycznej, [w:] Ruch prometejski i walka o przebudowę Europy Wschodniej (1918-1940). Studia i szkice, red. M. Kornat, Warszawa 2012.

Wszendyrówny A., Ekspozytura Nr 2 Oddziatu II Sztabu Gtównego Wojsk Polskiego, [w:] Ruch prometejski i walka o przebudowe Europy Wschodniej (1918-1940). Studia i szkice, red. M. Kornat, Warszawa 2012.

- artykuły w czasopismach naukowych:

Grzywacz A., Mazur G., Ruch prometejski w Polsce, „Zeszyty Historyczne” 1994, nr 110.

Karpiński W., Polski Prometeusz, „Zeszyty Historyczne” 2003, nr 147.

Kornat M., Ruch prometejski - ważne doświadczenie polityki zagranicznej II Rzeczypospolitej, „Nowa Europa Wschodnia” 2008, nr 2.

Kornat M., W kregu ruchu prometejskiego. Związek Zbliżenia Narodów Odrodzonych (1921-1923) i Instytut Wschodni w Warszawie (1925-1939), „Politeja” 2004, nr 2.

- artykuty prasowe:

Libera P., Polski prometeizm, jak ewoluowat i jak z nim walczono?, „Pressje” 2010, nr 22-23.

Łojek J., Idea federacyjna Józefa Pitsudskiego, „Libertas. Kwartalnik Społeczno-Polityczny” 1986, $\mathrm{nr} 6$.

Schaetzel T., Racja stanu Polski na wschodzie, „Pressje” 2010, nr 23. 


\section{Publikacje elektroniczne:}

W 1920 r. w polskich domach nieustannie przewijato się hasto „musisz iść do wojska”, wywiad z Andrzejem Nowakiem, [online] http://www.portal.arcana.pl/W-1920-r-w-polskich-domach-nieustannie-przewijalo-sie-haslo-musisz-isc-do-wojska,4011.html.

Bartosz ŚWIATŁOWSKI, absolwent stosunków międzynarodowych Wyższej Szkoły Europejskiej im. ks. Józefa Tischnera w Krakowie oraz polityki społecznej Uniwersytetu Jagiellońskiego. Student IV roku stosunków międzynarodowych UJ. Członek portalu Teologia Polityczna i Klubu Jagiellońskiego. Interesuje się polityką zagraniczną II i III Rzeczpospolitej, polityką wschodnią, myślą polityczną oraz publicystyką. 